\title{
RELAÇÕES ENTRE RACIONALIDADES NA GESTÃO ORGANIZACIONAL: UM ESTUDO DE CASO EM UMA INSTITUIÇÃO DE ENSINO SUPERIOR (IES) PRIVADAEMCURITIBA
}

\author{
Elizeu Alves ${ }^{1}$ \\ Samir Adamoglu ${ }^{2}$
}

\begin{abstract}
RESUMO
O presente artigo tem por objetivo analisar como ocorre a relação entre a racionalidade instrumental e a racionalidade substantiva na prática discursiva organizacional. A pesquisa foi de abordagem qualitativa, com delineamento descritivo e estudo de caso em uma IES da cidade de Curitiba (PR), seguindo corte seccional, com dados coletados através de entrevistas, triangulados com observação participante e análise documental. Verificouse a ocorrência de que tais racionalidades coexistem, se intricando em conflitos. Evidencia-se como o poder pode - e é usado - para conter, silenciar, gerenciar ou controlar tais conflitos de ações racionais. Conclui-se que tal relação ocorre de maneira a fazer coexistir as duas racionalidades; porém, o uso de poder simbólico ocorre para garantir a solução de conflitos racionais de modo a fazer com que a razão instrumental seja mascarada, dando a falsa sensação de uma inclinação para a razão substantiva, por meio de práticas discursivas.
\end{abstract}

Palavras-chave: Racionalidades; Aspectos Valorativos Educacionais; Poder Simbólico; Discurso; Gestão Organizacional de IES.

\section{RELACIONESENTRE RACIONALIDADESENLA GESTIÓNORGANIZACIONAL: UNESTUDIO DE CASO EN UNA INSTITUCIÓN DE ENSEÑANZA SUPERIOR (IES) PARTICULAR EN CURITIBA}

\section{RESUMEN}

El presente artículo tiene por objetivo analizar cómo ocurre la relación entre la racionalidad instrumental y la racionalidad sustantiva en la práctica discursiva organizacional. La investigación fue de abordaje cualitativo, con delineamiento descriptivo y estudio de caso en una IES de la ciudad de Curitiba (PR), siguiendo corte seccional, con datos recolectados a través de entrevistas, triangulados con observación participante y análisis documental. Se verificó la ocurrencia de que tales racionalidades coexisten, $\neg$ se intrincando en conflictos. Se evidencia cómo el poder puede - y se utiliza 
- para contener, silenciar, gestionar o controlar tales conflictos de acciones racionales. Se concluye que tal relación ocurre de manera a hacer coexistir las dos racionalidades; sin embargo, el uso de poder simbólico ocurre para garantizar la solución de conflictos racionales para hacer que la razón instrumental sea enmascarada, dando la falsa sensación de una inclinación hacia la razón sustantiva, por medio de prácticas discursivas.

Palabras clave: Racionalidades; Aspectos valorativos educativos; Poder simbólico; el habla; Gestión Organizacional de IES.

\title{
RELATIONS BETWEEN RATIONALITIES IN ORGANIZATIONAL MANAGEMENT: A CASE STUDYINA PRIVATE HIGHER EDUCATION INSTITUTION (HEI) INCURITIBA
}

\begin{abstract}
This article aims to analyze how is the relationship between instrumental rationality and substantive rationality in organizational discursive practice. The research was qualitative approach with descriptive design and case study in an HEI in Curitiba (PR), following a cross section, with data collected through interviews, triangulated with participant observation and document analysis. It was found that such rationalities coexist, entangling conflicts. It is evident how power can - and is used - to hold, mute, manage or control such conflicts of rational actions. It is concluded that this relationship occurs in order to make the two rationales coexist; however, the use of symbolic power occurs to ensure the solution of rational conflicts in order to mask the instrumental reason, giving a false sense of a tendency to a substantive reason, by means of discourse practices.
\end{abstract}

Keywords: Rationalities; Educational Valuation Aspects; Symbolic Power; Speech; IES Organizational Management.

\section{INTRODUÇÃO}

O ensino superior no Brasil é oferecido por Instituições de Ensino Superior (IES) as quais se classificam como universidades, centros universitários, faculdades, institutos superiores e centros de educação tecnológica, onde ofertam-se três tipos de graduação: o bacharelado, a licenciatura e a formação tecnológica (esta última mais conhecida como cursos superiores de tecnologia).

Na lógica estrutural, tais instituições se dividem em duas, onde de um lado se tem a organização mantenedora que é a da pessoa jurídica que provê os recursos 
necessários ao funcionamento da organização de ensino superior e é a sua representante legal. Enquanto a organização mantida é propriamente a instituição que realiza a oferta e a operacionalização da educação superior.

Com isso exposto, entendemos que tais organizações, na peculiaridade de seus papéis, reúnem características distintas, onde podemos visualizar as organizações mantenedoras a partir dos seus aspectos organizacionais de cunho racional pautados por cálculos utilitários de consequência baseados na racionalidade instrumental, e as organizações mantidas a partir de aspectos que se inclinam mais à emancipação humana através da educação.

Na questão da racionalidade, temos uma vertente crítica, onde alguns autores defendem que a educação superior no país possui uma inclinação mais para o instrumental, formando mão de obra para o mercado, sendo apenas uma instituição mercantilista, onde estes defendem a educação como uma vertente substantiva para a emancipação da vida associada. Desta forma, uma vez que tais racionalidades existem no mesmo espaço organizacional, onde essas permeiam a dinâmica do cotidiano das organizações, e por um ser inversiva à outra, temos os conflitos de ordem diretiva, isso entre as racionalidades e até mesmo intra-racionalidades.

Com isso, partimos da consideração de que, nas relações tensionadas e nas circunstâncias de conflitos nas organizações, o poder vem a ser o definidor dessa situação, seja pela capacidade política dos autores em disseminar sua opinião e pontos de vista, seja de maneira formal pelo cargo, ou ainda pela maneira simbólica, como, por exemplo 'a proximidade' do sujeito com a diretoria. Mesmo que nessa relação o poder entre as organizações seja assimétrico, em algumas circunstâncias essa assimetria pode se tornar simétrica. Essa consideração se amplia quando o objeto de estudo é entender a manifestação desses conflitos na organização mantenedora perante a sua mantida, sendo que tais racionalidades podem propiciar tal disputa de poder.

Isso na claridade das análises e comparações das diversas estruturas organizacionais, e o modo como às pessoas se relacionam e se comportam no ambiente de trabalho, nota-se que existem várias formas de exercer o poder dentro das 
organizações. Assim, podemos vislumbrar que desses relacionamentos e manifestações de poder o conflito emerge na vida organizacional. Existem várias circunstâncias que condicionam a construção das relações racionarias dos membros da organização, porém neste estudo, estamos olhando para o conflito como sendo a que nos interessa.

A presente pesquisa teve como pergunta condutora: Como ocorre a relação entre a racionalidade instrumental e substantiva na prática discursiva organizacional de uma instituição de ensino superior privada? Com isso, este estudo teve por finalidade discutir e analisar como ocorre a relação entre racionalidades na prática discursiva organizacional de uma IES, nesse caso, uma instituição, sediada em Curitiba, e com polos de atendimento para Educação à Distância em todo Brasil

Logo, analisar como ocorre a relação entre as racionalidades instrumental e substantiva em tais organizações se faz necessário para entender como estas se manifestam, e qual o seu trato para a coexistência dessa dinâmica. Além disso, este estudo se constituirá de um referencial para as IES, pois as questões aqui tratadas trarão luz a conflitos que muitas vezes podem ser ambíguos e contraditórios no contexto dessa relação, como também esses conflitos podem se manifestar na prática de ensino dos professores, os quais configuram o nível operacional da hierarquia organizacional da mantida.

E ressaltamos sua possível contribuição para a teoria, uma vez que, modestamente, tentará dar continuidade aos estudos sobre racionalidade iniciados por Guerreiro Ramos, e demais pesquisadores do tema. Portanto, tal tema sustenta relevância para o entendimento das relações racionais que existem em instituições de ensino superior, e qual o seu trato diante dessa dinâmica relacional.

Dividido em 5 seções, busca-se no presente artigo, inicialmente apresentar o contexto da educação superior no Brasil e o arranjo estrutural de IES. Posteriormente, destaca-se as concepções de racionalidades e conflito e poder nas organizações. E, seguido da delimitação do método da pesquisa, apresenta-se parte dos resultados obtidos na pesquisa que teve como objetivo a análise de como ocorre a relação entre a racionalidade instrumental e a racionalidade substantiva na prática discursiva organizacional de uma 
instituição de ensino superior privada (IES) e como tais racionalidades são compreendidas dentro dos aspectos valorativos educacionais. $\mathrm{O}$ artigo finaliza com as considerações finais e principais contribuições da pesquisa onde parte-se do pressuposto de que a escolha deste objeto de pesquisa abre espaço para discussão mais ampla sobre a educação superior no Brasil, pautando-se à partir dos estudos de racionalidades em processos organizacionais.

\section{REFERÊNCIAL TEÓRICO}

Apresentamos nesta sessão à construção dos fundamentos teóricos das categorias analíticas que comporão o estudo, com o objetivo de responder à pergunta de pesquisa. Inicialmente, iremos trabalhar reflexões em um nível mais macro necessário para se conceituar os contextos da educação superior e os contextos organizacionais de instituições de ensino superior, utilizando a tipologia proposta por Mintzberg (1995). Em seguida, trabalharemos a abordagem de racionalidades, fortemente ancorada nos estudos iniciados por Guerreiro Ramos, posteriormente por Maurício Serva e demais autores de estudos teórico-empíricos no tema. Por fim, articula-se o entendimento de que essa relação gera conflitos, podendo resultar no uso do poder como forma para abafar,gerenciar ou controlar tais conflitos.

\section{CONTEXTOS DA EDUCAÇÃO SUPERIOR NO BRASIL E DE INSTITUIÇÕES DE ENSINO SUPERIOR}

Desde a promulgação da Lei 9.394 de 20 de dezembro de 1996, Lei de Diretrizes e Bases da Educação (LDB), que definiu e regularizou o sistema de educação brasileiro, houve um crescimento do número das Instituições de Ensino Superior (IES) não públicas no cenário nacional. Segundo o Instituto Paranaense de Desenvolvimento Econômico e Social (IPARDES) (2013, p. 15) no município de Curitiba houve no ano de 2012 um total 
de 126.015 matrículas no ensino superior, divididas entre instituições particulares, estaduais e nacionais, sendo que as organizações privadas respondem por 75,41\% dessas matrículas. Igualmente, nesse mesmo período, houve 20.255 concluintes e as instituições particulares respondem por $82,39 \%$ desses egressos.

Para melhor compreensão, adiante se apresenta uma separação da temática, iniciando com a apresentação da questão social e valorativa de tais instituições para a sociedade, e em um segundo momento, apresentamos a questão de seu arranjo estrutural organizacional.

\section{A EDUCAÇÃO SUPERIOR NO BRASIL E AS IES COMO INSTITUIÇÕES SOCIAIS}

Remetendo-se à história da educação brasileira, temos a noção, segundo Colossi (1998) de que foi em 1808, com a chegada da família Real Portuguesa, que se iniciou a criação das primeiras escolas superiores, devido à influência das elites da sociedade de então.

Atualmente, o portal do Instituto Nacional de Estudos e Pesquisa Educacionais Anísio Teixeira - INEP (2017), ao divulgar o censo da educação superior em 2016, relata que o total de alunos chegou a mais de 8 milhões, ofertados em 2.407 IES, no total de 34.366 cursos de graduação. 0 censo apresentou que quase 3 milhões de alunos ingressaram em cursos de educação superior de graduação, sendo que desse total, 82,3\% em instituições privadas. Assim, nos faz sentido afirmar que desde a promulgação da LDB houve protagonismo das IES não públicas no cenário nacional. 0 papel da educação no Brasil é tema de inúmeras discussões e estudos. Para Colossi, Consentino e Queiroz (2001, p. 51):

A educação superior é uma instituição social, estável e duradoura, concebida a partir de normas e valores da sociedade. É, acima de tudo, um ideal que se destina, enquanto integrador de um sistema, à qualificação profissional e promoção do desenvolvimento político, econômico, social e cultural. 
Tal afirmativa vai ao encontro de Lopes (2010, p. 134):

É uma educação que catalisa o surgimento de rupturas, bifurcações, incertezas e a construção de outras possibilidades de universos não redutíveis às lógicas hegemônicas de determinada época. A essa educação, marcada pelo questionamento de verdades cristalizadas e legitimadora da ousadia de um aprender experimental, localizamos como partidária de uma política da invenção. Não uma política inventiva gestada em meio a destinos e utilidades teleologicamente planejados, mas sim mobilizada por uma permanente tensão "[...] entre a ação e a problematização.

Ainda temos a afirmação de Chauí (2003, p. 5) que defende a ideia de que "a universidade é uma instituição social e como tal exprime de maneira determinada a estrutura e o modo de funcionamento da sociedade como um todo". Na questão da racionalidade, temos uma vertente crítica, onde alguns autores defendem que a educação superior no país possui uma inclinação mais para o instrumental, formando mão de obra para o mercado, sendo apenas uma instituição mercantilista, onde estes defendem a educação como uma vertente substantiva para a emancipação da vida associada.

O papel da educação no Brasil é tema de inúmeras discussões e estudos. Para Colossi, Consentino e Queiroz (2001, p. 51):

A educação superior é uma instituição social, estável e duradoura, concebida a partir de normas e valores da sociedade. É, acima de tudo, um ideal que se destina, enquanto integrador de um sistema, à qualificação profissional e promoção do desenvolvimento político, econômico, social e cultural.

Tal afirmativa vai ao encontro de Lopes (2010, p. 134):

É uma educação que catalisa o surgimento de rupturas, bifurcações, incertezas e a construção de outras possibilidades de universos não redutíveis às lógicas hegemônicas de determinada época. A essa educação, marcada pelo questionamento de verdades cristalizadas e legitimadora da ousadia de um aprender experimental, localizamos como partidária de uma política da invenção. Não uma política inventiva gestada em meio a destinos e utilidades teleologicamente planejados, mas sim mobilizada por uma permanente tensão [...] entre a ação e a problematização. 
Ainda temos a afirmação de Chauí (2003, p. 5) que defende a ideia de que "a universidade é uma instituição social e como tal exprime de maneira determinada a estrutura e o modo de funcionamento da sociedade como um todo".

No artigo 43 da LDB, que trata das finalidades da educação superior no Brasil, temos o item três que fala sobre o desenvolvimento o entendimento do homem e do meio que vive, sendo esta a sociedade. Colossi (1998) argumenta que o ingresso e a busca de oportunidade de ensino superior são um alto valor para a sociedade brasileira. No Brasil, ensino superior é, acima de tudo, um sonho a ser realizado.

Chauí (2003, p. 7, grifo da autora) afirma que:

A visão organizacional da universidade produziu aquilo que, segundo Freitag ( $L e$ naufrage de l'université), podemos denominar como universidade operacional. Regida por contratos de gestão, avaliada por índices de produtividade, calculada para ser flexível, a universidade operacional está estruturada por estratégias e programas de eficácia organizacional e, portanto, pela particularidade e instabilidade dos meios e dos objetivos. Definida e estruturada por normas e padrões inteiramente alheios ao conhecimento e à formação intelectual, está pulverizada em microorganizações que ocupam seus docentes e curvam seus estudantes a exigências exteriores ao trabalho intelectual.

Na questão da educação e sua subversão a uma lógica instrumental, temos os conflitos de ordem da natureza inicial e valorativos da educação. Na afirmação de Veiga (2003, p. 271) encontramos que "olhando de modo mais específico, no que concerne ao projeto político-pedagógico, o processo inovador orienta-se pela padronização, pela uniformidade e pelo controle burocrático". Tal argumento encontra interface com Cunha e Fagundes:

As reformas educacionais retrataram os interesses político-econômicos que as produziram, vinculando a universidade às demandas da classe dirigente e à manutenção do status quo [...] 0 discurso da competência trouxe consigo a ênfase na competitividade, reforçada pela configuração do Estado mínimo cuja principal função residia na regulação social pelas regras do mercado. Projetos iniciantes em tempos anteriores viram-se desestimulados e a visão de futuro estabeleceuse numa perspectiva pragmática, afetando a universidade (CUNHA; FAGUNDES, 2012, p.27-28). 
No cerne dessa discussão, temos a explanação de Batista (2000, p. 184), onde “o professor é o mediador fragilizado entre o aluno e a instituição que dita as regras do jogo". Desta forma, segundo a autora em questão, e seu referencial para Adorno, temos:

\begin{abstract}
Professor enquanto mediador, postura tão efusivamente defendida pelas pedagogias progressistas, na realidade, depõe contra a docência no sentido de ser uma atividade de circulação: o professor tem se tornado mais e mais um vendedor de conhecimentos cada vez mais desqualificado pela sociedade por não reverter para si mesmo os lucros prováveis desta negociação (ADORNO, 1972 apud BATISTA, 2000, P. 184).
\end{abstract}

Na mesma concepção de docência, Chauí (2003, p.7), afirma que "a docência é entendida como transmissão rápida de conhecimentos, consignados em manuais de fácil leitura para os estudantes, de preferência ricos em ilustrações". Apontam-se como a questão central dos valores educacionais, os itens: (i) autonomia pedagógica; (ii) a lógica do aluno versus cliente; a (iii) a lógica do ensino-aprendizagem versus consumo-satisfação, e destes vão culminar em fé nas pessoas, consciência crítica, capacidade humana, dialogo e o entendimento entre emancipar $\mathrm{x}$ domesticar. Usamos tais informações para compor o quadro 1.

Quadro 1 - Aspectos valorativos educacionais

\begin{tabular}{|c|c|c|}
\hline Valores & Aspectos Valorativos Educacionais & Contradições \\
\hline $\begin{array}{l}\text { Autonomi } \\
\text { a } \\
\text { pedagógic }\end{array}$ & $\begin{array}{l}\text { Remete ao fato da concepção de } \\
\text { liberdade aos docentes com sua } \\
\text { validade enquanto recurso de } \\
\text { qualificação subjetiva e de formação de } \\
\text { uma visão social e política alternativa } \\
\text { no contexto da relação mercantil. }\end{array}$ & $\begin{array}{l}\text { Remete a falta de liberdade de } \\
\text { elaboração docente, onde este é } \\
\text { orientado a desenvolver o saber } \\
\text { passa a ser valorizado tão-somente } \\
\text { como meio de ascensão } \\
\text { econômica, }\end{array}$ \\
\hline & $\begin{array}{l}\text { Remete a relação entre alunos e } \\
\text { professor é uma relação onde o } \\
\text { primeiro age com aspectos valorativos } \\
\text { onde existe preocupações com a } \\
\text { importâncias orientadoras da } \\
\text { educação, tais como o princípio de } \\
\text { liberdade, criatividade, autonomia, } \\
\text { diálogo e interação comunicativa. }\end{array}$ & $\begin{array}{l}\text { Remete a relação entre alunos e } \\
\text { professor torna-se uma relação } \\
\text { entre mercador e clientes, } \\
\text { definindo-se a importância do } \\
\text { primeiro, não em função de sua } \\
\text { qualificação e formação, mas em } \\
\text { função da qualidade da mercadoria } \\
\text { de que é "vendedor". }\end{array}$ \\
\hline em ver & $\begin{array}{l}\text { dizagem } \\
\text { la sala de } \\
\text { resultado }\end{array}$ & $\begin{array}{l}\text { Remete ao professor sendo o } \\
\text { mediador fragilizado entre o aluno } \\
\text { e a instituição que dita as regras do }\end{array}$ \\
\hline
\end{tabular}




\begin{tabular}{|l|l|l|}
\hline consumo- & ao longo de sua formação, e tem plena \\
satisfação & $\begin{array}{l}\text { consciência que o aprender exige } \\
\text { estudo fora da sala de aula, postura } \\
\text { crítica e reflexão. }\end{array}$ & $\begin{array}{l}\text { jogondo o professor o agente da } \\
\text { formaça cultural, os professores } \\
\text { não sentindo formando, mas } \\
\text { deformando os alunos e a si } \\
\text { mesmos. Assim como a lógica do } \\
\text { aluno que espera um resultado } \\
\text { imediato. }\end{array}$ \\
\hline
\end{tabular}

Fonte: Elaborado pelo autor com base em Seno, Kappel e Valadão Júnior (2014); Batista (2000); Mühl (2009); e Chauí (2003).

Ainda sobre a educação superior no Brasil, temos um novo marco em 2004, quando foi criado o Sistema Nacional de Avaliação da Educação Superior (SINAES), reunindo às antigas métricas avaliativas e propondo uma nova forma de se avaliar.

Art. 10 Fica instituído o Sistema Nacional de Avaliação da Educação Superior - SINAES, com o objetivo de assegurar processo nacional de avaliação das instituições de educação superior, dos cursos de graduação e do desempenho acadêmico de seus estudantes, nos termos do art 9o, VI, VIII e IX, da Lei no 9.394, de 20 de dezembro de 1996 (BRASIL, 2004).

Dentro de tais dimensões avaliativas propostas, nos chama a atenção os tópicos VI e X, pois esses traduzem a concepção emancipatória do ensino superior e sua oferta como um bem público.

VI - organização e gestão da instituição, especialmente o funcionamento e representatividade dos colegiados, sua independência e autonomia na relação com a mantenedora, e a participação dos segmentos da comunidade universitária nos processos decisórios

$(\ldots)$

$\mathrm{X}$ - sustentabilidade financeira, tendo em vista o significado social da continuidade dos compromissos na oferta da educação superior (BRASIL, 2004).

Atenta-se a questão da sustentabilidade financeira, pois está visa a manutenção do significado social das IES, Farinelli e Melo (2009, p. 2) esclarece que "a legislação brasileira permite que instituições privadas ofereçam um serviço que é considerado de utilidade pública, isto é, permite que um empresário coloque em funcionamento uma instituição de ensino superior (IES)". Por fim, Rothen e Shulz (2005) e Bertolin (2004) (apud BARREYRO; ROTHEN, 2006, p. 963, grifos do autor) salientam:

Na proposta da Comissão Especial de Avaliação da Educação Superior (CEA), a função principal da avaliação é entendida como emancipatória e o agente principal é a comunidade interna das IES, como no Programa de Avaliação Institucional das Universidades Brasileiras (PAIUB); por sua vez, na lei, a função 
Tal explicação sobre o SINAES aqui nos é válida, pois, desde a promulgação da LBD em 1996, esse é um dos poucos atos legislativos educacionais dos últimos governos que, desde então, implicou a criação de um sistema de avaliação, e não apenas o uso de instrumentos isolados estabelecidos por leis, decretos e portarias ministeriais que existiam antes dela. Igualmente, nos é relevante, pois, quando tratamos de avaliação, estamos pensando em métricas que, em muitos casos, podem se tornar formas de buscar resultados majoritariamente pautados pelo cálculo utilitário de consequências, trazendo assim, novamente, o conflito entre racionalidades.

\section{ARRANJO ESTRUTURAL DE IES}

Uma IES se caracteriza pela junção de duas organizações que se necessitam mutualmente para existir, isso vale para as IES públicas e privadas. Tais organizações recebem o nome de mantenedora e de mantida. Quando procuramos descrever os arranjos estruturais de uma IES, o estudo de Mintzberg (1995) mostra um modo tipológico de se entender a coerência estrutural das organizações, com seus mecanismos de coordenação em informalidade em uso (ou ajuste mútuo), autoridade no uso da supervisão (supervisão direta) e padronização de processos, resultados ou de habilidades. Os tipos ideais propostos por Mintzberg (1995) podem ser sintetizados no quadro 2 (dois).

Quadro 2 - Características das configurações estruturais propostas por Mintzberg (1995)

\begin{tabular}{|l|l|}
\hline Estrutura & Características \\
\hline
\end{tabular}




\begin{tabular}{|l|l|}
\hline \multirow{3}{*}{$\begin{array}{l}\text { Burocráti } \\
\text { co- } \\
\text { Mecânica }\end{array}$} & $\begin{array}{l}\text { Ocorre em organizações geralmente de maior dimensão que as simples. } \\
\text { As características dominantes fundem-se numa "organização por } \\
\text { funçes", muito estruturada e baseada numa separação clara entre o } \\
\text { pessoal de concepção e o pessoal de execução. Principal mecanismo de } \\
\text { coordenação é a padronização dos processos de trabalho, sendo que a } \\
\text { tecnoestrutura apresenta papel preponderante neste tipo de organização, } \\
\text { pois faz elevada pressão para a estandardização dos processos. }\end{array}$ \\
\hline \multirow{3}{\text{Burocraci}}{$\begin{array}{l}\text { Opondo-se à Burocracia Mecânica, substitui a autoridade da posição } \\
\text { fundada na autoridade hierárquica pela autoridade de competência que } \\
\text { Profissio } \\
\text { nal }\end{array}$} & $\begin{array}{l}\text { se baseia no profissionalismo. Passou-se da padronização dos processos } \\
\text { de trabalho à padronização das qualificações dos intervenientes. Esta } \\
\text { configuração encontra-se sobretudo nos hospitais, nas universidades e } \\
\text { escolas, gabinetes de advocacia; funciona através das qualificações e } \\
\text { competências dos profissionais que ali operam. }\end{array}$ \\
\hline
\end{tabular}

Fonte: Adaptado de Mintzberg (1995, p. 158-250).

Com tais tipos ideais propostos por Mintzberg (1995), podemos entender uma IES analogamente a duas dessas configurações. A organização mantenedora tende a ser similar a uma burocracia-mecânica, uma vez que ela obedece à legislação vigente, possuindo contrato social que regulamenta o seu funcionamento interno, sendo a mantenedora a pessoa jurídica que goza das responsabilidades administrativas, tais como: as contratações dos profissionais (administrativos, docentes e serviços em geral) que prestam serviço para a mantida; as responsabilidades financeiras e contábeis tais como controle do orçamento, recebimentos, políticas de preço e descontos; as responsabilidades jurídicas de representação judicial e extrajudicial da mantida; e, por fim, as responsabilidades estruturais para o funcionamento da mantida.

Em contrapartida, podemos entender a organização mantida similarmente ao tipo ideal de burocracia profissional que, em função do seu regimento, oferece a prestação de serviços educacionais, sendo sua divisão em campos de estudos nos qual a competência do professor/coordenador é o que prevalece. Por exemplo, uma pessoa que possua formação na área biológica, não irá coordenar cursos na área de gestão.

Uma vez que a organização mantida necessita da mantenedora para existir e depende dela para o seu funcionamento, os conflitos, que já são inerentes à vida organizacional, podem levar tais organizações ao fracasso quando esses extrapolam os limites toleráveis, havendo uma curvatura na definição e no cumprimento dos objetivos que nascem da mantenedora para com a mantida e vice-versa. Tais conflitos se manifestam nas relações entre elas, principalmente na questão racional. 


\title{
RACIONALIDADES
}

Ao se analisar a origem filosófica da racionalidade, faz-se necessário entender que essa se encontrava na necessidade de buscar explicações satisfatórias sobre fenômenos da natureza. Segundo Chauí (2000, p. 71) “a razão é a capacidade intelectual para pensar e exprimir-se correta e claramente, para pensar e dizer as coisas tais como são. A razão é uma maneira de organizar a realidade pela qual esta se torna compreensível".

Segundo Ramos (1981 apud PAULA, 2007, p. 178):

\begin{abstract}
Para realizar a crítica da razão, o autor resgata os seus sentidos antigo e moderno. No sentido antigo, a razão era entendida como a capacidade de distinguir entre o bem e o mal, o falso e o verdadeiro. No sentido moderno, a razão procura legitimar a sociedade moderna exclusivamente em bases utilitárias, despojandose de qualquer papel na construção da vida humana individual. Isto teria escandalizado Max Weber, que então fez uma distinção entre a racionalidade formal e instrumental (Zweckrationalität), que é determinada por uma expectativa de resultados, ou "fins calculados", e a racionalidade de valor ou substantiva (Wertrationalität), que é determinada independentemente de suas expectativas de sucesso.
\end{abstract}

Tal movimento teve seu ápice na segunda metade do Século XIX onde, segundo Carvalho (2009a), a doutrina positivista havia conquistado um espaço que transcendia a academia. Diferentemente da filosofia metafísica, os positivistas procuravam dar um 'tratamento científico' às questões sociais, o que na prática significava a tentativa de construção de uma 'física social'. O modelo comteano de sociedade se embasava numa ideia evolucionista, a partir de estruturas mais básicas até as mais complexas, através de um caminho linear que, se devidamente equacionado, podia ser previsível e, portanto, controlável. Com isso, esse cientificismo positivista representou uma tentativa elaborada de aproximação da ciência (entenda-se, primordialmente, a física) com a sociedade, que se deu por meio da política, de instituições e de religiões.

Assim, a razão, que nasceu com a pretensão de libertar os homens do domínio do mito, torna-se um novo mito encarnado na ciência positiva e no mundo burocratizado. Ao assumir uma forma positivista, ao se instrumentalizar, a razão perde a sua dimensão principal - a reflexividade -, e já não se pergunta sobre seus pressupostos nem sobre seu sentido; é uma racionalidade que substitui os fins pelos meios, agindo na esfera do como, sem se perguntar pelo porquê. Isso produz a reificação não somente do mundo exterior, mas, também, da subjetividade humana. (ADORNO; HORKEIMER, 1986 apud MÜHL, 2009, p. 254) 
Ramos (1989, p. 23, grifo nosso) afirma que "a razão é o conceito básico de qualquer ciência da sociedade e das organizações. Ela prescreve como os seres humanos deveriam ordenar a sua vida pessoal e social". Assim, Barreto (1993 apud ANDRADE; TOLFO; DELLAGNELO, 2012, p. 206, grifo do autor) explica que:

0 "termo racionalidade refere-se a uma capacidade que se presume ser exclusiva da espécie humana, utilizada para ponderar, julgar, estabelecer relações lógicas e praticar bom senso. A raiz do termo racionalidade está na palavra razão, do latim ratione, a qual consiste no raciocínio".

Ramos (1989) apresenta também que a racionalidade funcional ou instrumental pode ser definida como ação baseada no cálculo, cuja qualidade e conteúdo inerentes as ações são orientadas para alcance de metas técnicas ou finalidades ligadas a interesses econômicos com fins almejados e preestabelecidos e diz respeito a condutas, eventos ou objetos para atingir determinado objetivo.

Na questão da racionalidade substantiva, Ramos (1989) explica que racionalidade substantiva é um atributo natural do ser humano, visto que reside na psique humana e é a partir dela que os indivíduos podem buscar conduzir sua vida pessoal na direção da autorealização e do autodesenvolvimento, engajando-se de forma mais expressiva no processo de desenvolvimento social e, no âmbito da teoria administrativa, no processo de desenvolvimento da própria organização.

O quadro proposto por Serva $(1996 ; 2015)$ foi a forma pioneira de observar empiricamente como se manifestam a racionalidade instrumental e a racionalidade substantiva, na prática administrativa. Tal instrumento foi elaborado em sua tese de doutorado - onde ele alinhou as reflexões de Guerreiro Ramos e a Teoria da Ação Comunicativa de Habermas - e foi um dos primeiros trabalhos a tentar resolver o impasse no campo. Serva (1996; 2015) afirmou que, após a morte de Guerreiro Ramos, os estudos de racionalidade nas organizações avançaram, porém careciam até então de abordar a manifestação da racionalidade instrumental e substantiva, empiricamente. 
Quadro 3 - Modelo de análise da racionalidade substantiva nas organizações por Serva (1996; 2015)

\begin{tabular}{|c|c|c|}
\hline $\begin{array}{l}\text { Processos } \\
\text { Organizacionais }\end{array}$ & $\begin{array}{l}\text { Racionalidade } \\
\text { Substantiva }\end{array}$ & $\begin{array}{l}\text { Racionalidade } \\
\text { instrumental }\end{array}$ \\
\hline Hierarquia e normas & $\begin{array}{l}\text { Entendimento } \\
\text { Julgamento ético }\end{array}$ & $\begin{array}{c}\text { Fins, desempenho } \\
\text { Estratégia interpessoal }\end{array}$ \\
\hline Valores e objetivos & $\begin{array}{c}\text { Autorealização } \\
\text { Valores emancipatórios } \\
\text { Julgamento ético }\end{array}$ & $\begin{array}{c}\text { Utilidade } \\
\text { Fins } \\
\text { Rentabilidade }\end{array}$ \\
\hline Tomada de decisão & $\begin{array}{l}\text { Entendimento } \\
\text { Julgamento ético }\end{array}$ & $\begin{array}{c}\text { Cálculo, utilidade } \\
\text { Maximização recursos }\end{array}$ \\
\hline Controle & Entendimento & $\begin{array}{l}\text { Maximização recursos } \\
\text { Desempenho } \\
\text { Estratégia interpessoal }\end{array}$ \\
\hline Divisão do trabalho & $\begin{array}{c}\text { Autorealização } \\
\text { Entendimento } \\
\text { Autonomia }\end{array}$ & $\begin{array}{l}\text { Maximização recursos } \\
\text { Desempenho } \\
\text { Cálculo }\end{array}$ \\
\hline $\begin{array}{l}\text { Comunicação e Relações } \\
\text { interpessoais }\end{array}$ & $\begin{array}{c}\text { Autenticidade } \\
\text { Valores emancipatórios } \\
\text { Autonomia }\end{array}$ & $\begin{array}{c}\text { Desempenho } \\
\text { Êxito/Resultados } \\
\text { Estratégia interpessoal }\end{array}$ \\
\hline $\begin{array}{l}\text { Ação social e Relações } \\
\text { ambientais }\end{array}$ & Valores emancipatórios & $\begin{array}{c}\text { Fins } \\
\text { Êxito/Resultados }\end{array}$ \\
\hline $\begin{array}{lll}\begin{array}{l}\text { Reflexão } \\
\text { organização }\end{array} & \text { sobre } & \text { a } \\
\end{array}$ & $\begin{array}{l}\text { Julgamento ético } \\
\text { Valores emancipatórios }\end{array}$ & $\begin{array}{c}\text { Desempenho } \\
\text { Fins, rentabilidade }\end{array}$ \\
\hline Conflitos & $\begin{array}{c}\text { Julgamento ético } \\
\text { Autenticidade } \\
\text { Autonomia }\end{array}$ & $\begin{array}{c}\text { Cálculo } \\
\text { Fins } \\
\text { Estratégia interpessoal }\end{array}$ \\
\hline Satisfação individual & $\begin{array}{c}\text { Autorealização } \\
\text { Autonomia }\end{array}$ & $\begin{array}{c}\text { Fins, Êxito } \\
\text { Desempenho }\end{array}$ \\
\hline Dimensão simbólica & $\begin{array}{c}\text { Autorealização } \\
\text { Valores emancipatórios }\end{array}$ & $\begin{array}{c}\text { Êxito/Resultados } \\
\text { Utilidade, Desempenho }\end{array}$ \\
\hline
\end{tabular}

Fonte: Serva (1996, p. 339)

O quadro proposto por Serva $(1996 ; 2015)$ alinhado com a reflexão dos aspectos valorativos da educação apresentados no quadro 01 servirão como referencial nesta proposta de estudo na forma de entender, capturar e analisar - empiricamente - as relações entre as racionalidades.

Neste estudo optaremos por adotar e explorar os seguintes processos organizacionais: (i) Valores e objetivos; (ii) tomada de decisão; (iii) controle e (iv) conflitos, pois consideramos que nesses tópicos existe uma pré-disposição para se analisar a relação 
preconizada, uma vez que os valores e objetivos são os marcos zero de todas as organizações; assim, para mantê-los e alcançá-los, eles passam por decisões e controles que irão condicionar circunstâncias de conflitos e suas resoluções. Por exemplo, a questão do pressuposto de rentabilidade para a mantenedora pode não ser a mesma apresentadas no início deste projeto de estudo. Dessa forma, a questão passa a ser como se está solucionando - se é que está - essa relação de conflituosa entre racionalidades, se há o uso do poder nesse processo, e como este se dá.

Quando fazemos uma ponte entre a tipologia das organizações proposta por Mintzberg (1995) e o quadro de análise de racionalidades proposto por Serva (1996; 2015), podemos observar que a organização mantenedora possui uma inclinação para a racionalidade instrumental no sentido elemento 'fins' para o processo organizacional de controle, pois a sua estrutura está mais voltada para as metas de natureza econômica, maximização de recursos e desempenho onde, para tanto, necessita de processos mecanizados - característica estruturais de uma burocracia mecânica. Por outro lado, a organização mantida tem uma inclinação para a racionalidade substantiva no sentido do elemento 'entendimento' para o mesmo processo organizacional onde sua estrutura está mais voltada para o consenso mediada pela livre comunicação, mudando assim de autoridade de hierarquia para a autoridade de competência, característica de uma burocracia profissional, Neste entendimento, podemos vislumbrar que uma IES é a junção de duas organizações que se diferenciam em seu arranjo estrutural.

Por fim, entende-se que a racionalidade instrumental se caracteriza por uma visão utilitarista onde suas ações baseadas no cálculo objetiva única e exclusivamente o alcance de metas técnicas ligadas ao interesse econômico, sendo esta individualista no sentido de que se perde os valores éticos em seu julgamento e a racionalidade substantiva trata a racionalidade substantiva está voltada para a valorização do ser humano de forma individual e coletiva fundamentada nos padrões éticos que permitem aos indivíduos julgar e mensurar determinados acontecimentos. 
Paula (2007, p. 176), descreve que:

Para Guerreiro Ramos, o espaço da organização é o espaço da ética da responsabilidade, pois no mundo das organizações a tolerância com singularidades que manifestam os valores e as convicções das personalidades é bastante limitada. A questão crucial para Guerreiro Ramos é que o predomínio da ética da responsabilidade torna a irredutibilidade do indivíduo à organização um fato básico, quase inquestionável. No entanto, uma vez que todo ser humano tem o direito de se personalizar, as pessoas continuam cultivando valores e agindo segundo a ética da convicção. Por este motivo, as organizações são constantemente permeadas por uma tensão entre éticas, uma oposição entre racionalidade funcional e racionalidade substantiva.

Assim, podemos identificar que no modelo de sistema centrado no mercado, estamos restritos à lógica utilitarista, e isso inibe a manifestação prática da racionalidade substantiva, mesmo esta coexistindo ao lado da instrumental. Com efeito, é plausível que se encontrem conflitos entre as racionalidades em sua aplicação prática, e é nesse contexto que figura a IES considerada para esta proposta de estudo.

\section{CONFLITO E PODER NAS RELAÇÕES ORGANIZACIONAIS}

Nesse tópico, iremos apresentar em separado o arcabouço teórico de conflitos e de poder para melhor visualização.

\section{CONFLITO NAS ORGANIZAÇÕES}

Ao estudarmos as relações de conflitos e poder nas organizações, colocamo-nos diante de fatores de significativa importância na estruturação social, e isso se reflete na vastidão teórica em que inúmeros autores procuram compreender tais fenômenos sociais, seja em seu conjunto, seja com ênfase em algum ponto específico, como o poder formal e o simbólico, por exemplo. 
Nesse sentido, nossa proposta de abordagem neste trabalho é a lógica em que a tensão de duas racionalidades em uma organização por si só já traria conflitos, no caso de uma IES que é composta de duas organizações com objetivos distintos e de mútua necessidade de existência se ampliam as tensões, e esta se torna manifesta através do conflito. E, em meio a esse impasse, temos o uso do poder (seja ele simbólico ou formal) para destacar qual racionalidade se manifestará com mais força, acarretando em diferentes efeitos. Nesse entendimento, a tensão é algo que não pode ser captado de forma pura, mas apenas em sua manifestação, em ações ou práticas que tangibilizem o ato, tal qual o conflito. Conforme Stohl e Cheney (2001, p. 384-385, tradução nossa),

As tensões inevitavelmente surgem nas relações dinâmicas entre os indivíduos, grupos e da organização maior como eles se esforçam para atingir seus objetivos dentro do contexto de cooperação. Cada unidade está engajada em uma luta contínua entre atender as demandas dos sistemas sociais e fazendo exigências dos sistemas sociais.

O conflito surge por causa de tensões, de divergências que podem ocorrer no nível individual e intergrupal de uma organização, sendo ele a parte manifesta das tensões, assim, com efeito, podemos sintetizar que as diferenças de racionalidade provocam ou condicionam tensões que podem irromper em conflitos onde o uso do poder, pode ser uma via para abafar, gerenciar ou controlar tais conflitos.

Ainda quando abordamos a questão dos conflitos, temos que vislumbrar o grau de relevância de cada uma das situações conflituosas, destacando os conflitos centrais e os periféricos em tais relações, tendo em vista que na variância de grau de conflitos, teremos atuações e usos de poder de forma diferenciada, ou seja, com esforços e objetivos diferentes. Nesta questão de grau, temos o quadro 4, com a classificação de níveis apresentados por Nascimento e Sayed (2002).

Quadro 4 - Níveis de Conflitos de Nascimento e Sayed 


\begin{tabular}{|l|l|}
\hline Conflito latente & $\begin{array}{l}\text { São os conflitos não declarados e não há, mesmo por parte } \\
\text { dos elementos envolvidos, uma clara consciência de sua } \\
\text { existência. }\end{array}$ \\
\hline Conflito percebido & $\begin{array}{l}\text { São os conflitos onde os elementos envolvidos percebem, } \\
\text { racionalmente a existência do conflito, embora não haja } \\
\text { ainda manifestações abertas do mesmo. }\end{array}$ \\
\hline Conflito sentido & $\begin{array}{l}\text { São os conflitos que já atingem ambas as partes, e em que há } \\
\text { emoção e forma consciente. }\end{array}$ \\
\hline Conflito manifesto & $\begin{array}{l}\text { São os conflitos que já atingiram ambas as partes e já é } \\
\text { percebido por terceiros e pode interferir na dinâmica da } \\
\text { organização. }\end{array}$ \\
\hline
\end{tabular}

Fonte: Adaptado de Nascimento e Sayed (2002, p. 50).

Assim, o grau de manifestação do conflito é o que irá condicionar o uso do poder para contê-lo, gerenciá-lo ou controla-lo, tal conceituação visa demonstrar a concepção de conflitos, onde já temos a concepção de Serva $(1996 ; 2015)$ para a sua resolução, sendo do lado instrumental o cálculo, fins e estratégia interpessoal (essa com uso do poder) e do lado substantivo temos as formas de julgamento ético, autenticidade e autonomia.

\section{PODER NAS ORGANIZAÇÕES}

O poder vem sendo estudado no intuito de entender sua manifestação na vida das organizações. Neste estudo consideramos o trabalho de Pierre Bourdieu, que nos chama a atenção para os fenômenos de percepção social, produção simbólica e relações informais de poder, e nos conceitos-chave de habitus, capital simbólico e campo, desenvolvidos por ele. Na questão de habitus, o temos:

Como sistema das disposições socialmente constituídas que, enquanto estruturas estruturantes, constituem o princípio gerador e unificador do conjunto das práticas e das ideologias características de um grupo de agentes (BOURDIEU, 2005, p. 191).

Isso remete à questão de "campo" que, para Bourdieu (2005), têm suas próprias regras, princípios e hierarquias. São definidos a partir dos conflitos e das tensões no que diz respeito à sua própria delimitação e construídos por redes de relações ou de oposições entre os atores sociais que são seus membros. Em outras palavras:

O campo, no seu conjunto, define-se como um sistema de desvio de níveis diferentes e nada, nem nas instituições ou nos agentes, nem nos atos ou nos discursos que eles produzem, têm sentido senão relacionalmente, por meio do jogo das oposições e das distinções (BOURDIEU, 2001, p. 179). 
Com isso, temos o que Bourdieu (2001) defende como a existência do poder simbólico, mediante o qual as classes dominantes (ou campos dominantes) são beneficiárias de um capital simbólico, disseminado e reproduzido por meio de instituições e práticas sociais, que lhes possibilitam fazer uso do poder.

O capital simbólico - outro nome da distinção - não é outra coisa senão o capital, qualquer que seja a sua espécie, quando percebido por um agente dotado de categorias de percepção resultantes da incorporação da estrutura da sua distribuição, quer dizer, quando conhecido e reconhecido como algo de óbvio (BOURDIEU, 2001, p. 145).

Assim, entende-se que tal capital simbólico deriva de um poder simbólico que para Bourdieu (2001, p. 9; 177, grifo do autor):

Um poder que aquele que lhe está sujeito dá àquele que o exerce, um crédito com que ele o credita, um fide, uma auctoritas, que lhe confia pondo nele a sua confiança. É um poder que existe porque aquele que lhe está sujeito crê que ele existe. [...] 0 poder simbólico é um poder de construção da realidade que tende a estabelecer uma ordem gnoseológica: o sentido imediato do mundo (e, em particular, do mundo social) supõe aquilo a que Durkheim chama o conformismo lógico, quer dizer, "uma concepção homogênea do tempo, do espaço, do número, da causa, que torna possível a concordância entre as inteligências".

Nesse sentido, Bourdieu (2001) relata que as estruturas estruturadas, tais como a língua, as culturas, o discurso ou a conduta, por exemplo, funcionam como intermediários estruturados construídos para explicar a relação entre objeto simbólico e sentido - que para o estudo a ser aqui apresentado, faz sentido, pois o uso do poder na resolução de conflitos gerados por tensões entre racionalidades pode ser da ordem simbólica, e não apenas da ordem do plano formal ou formalizado, dentro de uma organização. Na questão das palavras e discursos, Bourdieu (1996, p. 87, grifo nosso):

0 poder das palavras é apenas o poder delegado do porta-voz cujas palavras (quer dizer, de maneira indissociável, a matéria de seu discurso e sua maneira de falar) constituem no máximo um testemunho, um testemunho entre outros da garantia de delegação de que ele está investido.

Assim, para que isso aconteça, Bourdieu (2001) afirma ser necessária a presença de universos nos quais as estruturas objetivas sejam capazes de se reproduzir nas 
assinala os ritos de instituição que criam separação entre os "iniciados" e os "nãoiniciados", que aqui podemos interpretar como tempo de empresa ou prestigio político, por exemplo. Em tais circunstâncias de estudo nos é de grande valia utilizar das concepções de tal autor, principalmente se alinharmos aos estudos de Rosa, Paço-Cunha e Morais (2009, p. 81) que afirmam que:

Pierre Bourdieu e a análise crítica do discurso (ACD) desenvolvida no âmbito da linguagem critica. Ambas as perspectivas se aproximam na medida que percebem a linguagem como uma prática social, mediada pelo poder e dependente de um contexto social de produção.

Entender os conflitos que envolvem os indivíduos e os grupos em uma organização é buscar entender em que momento se manifestam as diferenças relacionais nas organizações. Existem várias circunstâncias que condicionam a construção das relações racionarias dos membros da organização, porém neste estudo, olhamos para o conflito como sendo a que nos interessa.

\section{MÉTODO E APRESENTAÇÃO DOS DADOS}

A pesquisa aqui apresentada foi de natureza qualitativa, caracterizando-se como descritiva, e almejando entender como ocorre a relação entre a racionalidade instrumental e substantiva na prática de gestão organizacional de uma instituição de ensino superior privada, neste caso, uma IES, de classificação Centro Universitário. Segundo Braga (2007), a pesquisa descritiva tem o objetivo de identificar as características de um determinado problema ou questão e descrever o comportamento dos fatos e fenômenos. Para tal descrição, utilizou-se como estratégia de investigação empírica o estudo de caso. 
Quando a temática é o estudo de caso, existem inúmeros autores que abordam o tema, como por exemplo, Yin (2005), Eisenhardt (2007), Hartley (2004), Stake (2000), Godoy (2006), dentre outros. Neste estudo iremos ancorar nossa forma de investigação na abordagem proposta por Yin (2005) uma vez que, na maioria dos estudos teóricoempíricos sobre racionalidade realizados no país, foram este método e autor empregados. Nesse sentido, além da prática dos autores no uso do autor ilustrar estudos referenciais em seus resultados, consideramos também que tal uso já está validado nos estudos de racionalidade.

A questão central desta pesquisa pode ser sintetizar em: como ocorre a relação entre a racionalidade instrumental e substantiva na prática discursiva organizacional de uma instituição de ensino superior privada?

E, para responder ao questionamento anterior é necessário fazer as seguintes perguntas:

1. Como se estrutura a IES na forma de suas organizações mantenedora e mantida abordadas?

2. Essa estruturação dá margem a conflitos de racionalidade?

3. Como se manifestam as racionalidades nessas organizações e em suas relações?

4. Como se percebem manifestações de conflitos de racionalidade na organização mantida?

5. Como se materializa o conflito de racionalidade na relação entre essas organizações?

6. Como é exercido o poder na mediação entre esses conflitos de racionalidade?

7. Como se percebem tais manifestações de conflitos de racionalidade no corpo docente, sendo que este é o último a ser afetado por elas?

Com isso, temos na disposição das categorias de análise deste estudo, o raciocínio se dá conforme as diferenças entre racionalidades instrumental e substantivas, principalmente no que se refere aos aspectos valorativos educacionais e de como tais diferenças indivíduos (dentro de um mesmo grupo), entre grupos (intergrupos) distintos numa 
organização, ou entre duas ou mais organizações. Por fim, visando 'abafar'/gerenciar/controlar o conflito (ou a circunstância conflituosa), recorre-se a algum tipo de exercício de poder. Na figura 1, temos uma disposição ilustrativa das categorias centrais desse trabalho.

Figura 1: Representação das categorias de análise

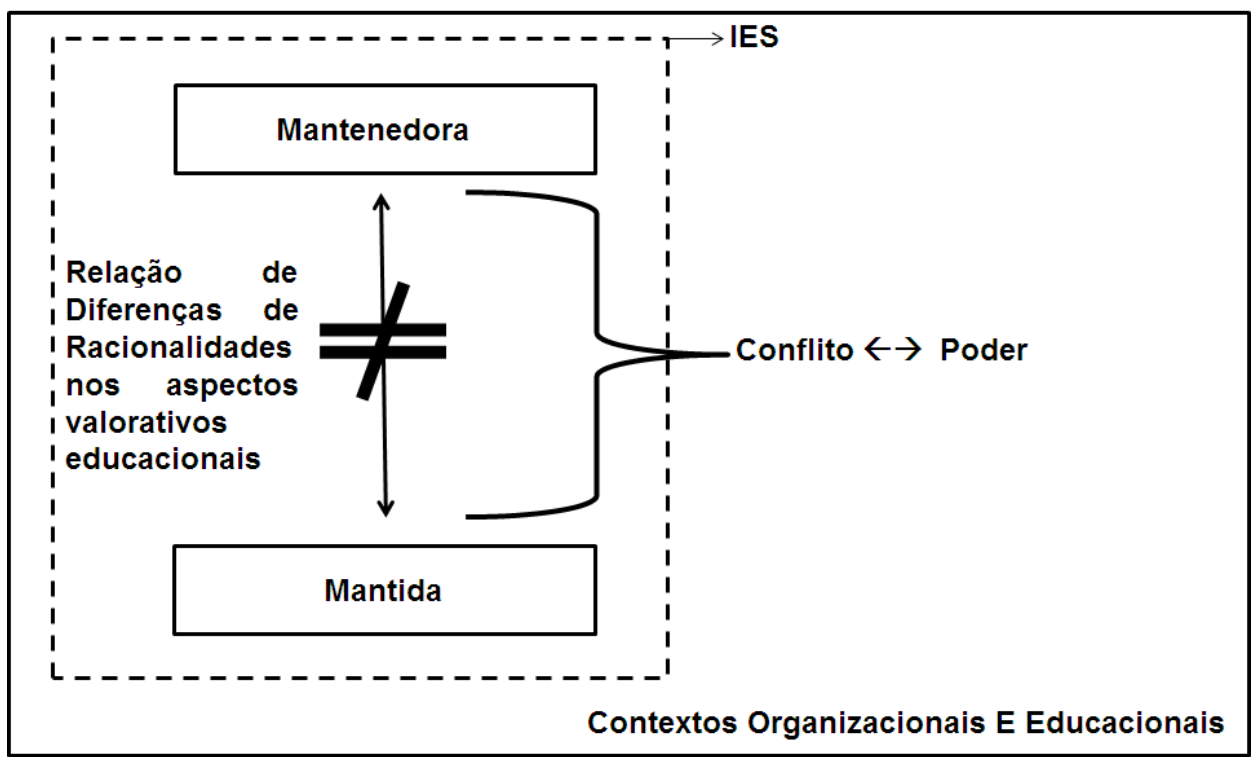

Fonte: Os autores

No caso do estudo aqui intencionado, por suas características, utilizamos a validade do constructo com a triangulação dos dados, buscando a convergência das informações. A triangulação deu-se por meio de observação participante, entrevistas e análise de documentos. Além das entrevistas e análise de documento, utilizamos o método de observação participante, com o cuidado, porém, de as preconcepções do pesquisador não contaminarem a investigação.

De tais coletas conseguirmos reunir os documentos constantes na tabela 1. 
Tabela 1 - Documentos coletados

\section{Dados Primários}

\begin{tabular}{|c|c|c|}
\hline 12 Entrevistas & \multicolumn{2}{|l|}{ Total de Páginas: 237} \\
\hline 07 Eventos Observados & \multicolumn{2}{|l|}{ Total de Páginas: 29} \\
\hline \multicolumn{3}{|c|}{ Dados Secundários } \\
\hline 67 Comunicados Internos & \multirow{5}{*}{$\begin{array}{l}\text { Após Análise de Conteúdo } \\
\text { (Bardin, 2010) ? }\end{array}$} & 10 \\
\hline 11 Manuais & & 06 \\
\hline 79 Resoluções & & 17 \\
\hline $\begin{array}{ll}05 & \text { Propósitos } \\
\text { Organizacionais } & \end{array}$ & & 03 \\
\hline 07 Atas de reuniões & & 04 \\
\hline
\end{tabular}

Fonte: Os autores

$\mathrm{Na}$ realização das entrevistas, inicialmente traçamos o perfil e o motivo para entrevistá-lo(a) e sua escolha foi traçada de modo a que se alcançasse as respostas para o estudo, buscando entrevistar inúmeros atores que (i) ou são decisores diretos, (ii) ou decisores indiretos, até (iii) atores que são unicamente atingidos pelas decisões.

Para a realização da observação participante, uma vez que o pesquisador teve acesso laboral ao contexto que está sendo pesquisado, desenvolvemos um guia de observação onde constam os elementos que foram observados para a coleta de dados.

Paralelamente à observação participante e às entrevistas, o pesquisador fez uso de dados secundários, que foi a análise de documentos das organizações. Para isso, decidimos que iríamos analisar os principais documentos da organização, que vão desde sua concepção até os informativos aos colaboradores. Foram analisados (i) comunicados internos que são a principal forma de comunicação entre a organização e seus funcionários; (ii) manuais comportamentais que descrevem como as situações devem se desenvolver, sendo uma forma de orientar as ações humanas dentro das organizações; (iii) resoluções administrativas-acadêmicas que são as resoluções que vão disciplinar assuntos do interesse interno, é ela que vai normatizar procedimentos; (iv) propósitos organizacionais que são aqueles documentos que tratam da constituição e procedimentos regimentais; e atas de reuniões onde fizemos um corte e analisamos somente as atas de reuniões do ano de 2014, a escolha se deu para o cruzamento com as circulares internas. 
Após o levantamento desses documentos, realizamos uma análise de conteúdo baseada em Bardin (2010) e realizamos a seleção dos documentos que efetivamente iriam compor os dados de análise. Neste caso, para a análise, utilizamos como lente as categorias de Serva $(1996 ; 2015)$ para a descrição de cada item de racionalidade, e, uma vez que tal fonte analisada não continha tais traços previamente descritos por Serva ou então sem conexão com as reflexões de Guerreiro Ramos e aos aspectos valorativos educacionais, o documento era descartado, não vindo a compor os mapas de associação de ideias. Por exemplo, havia um documento que era apenas informativo, dizendo os dias de pagamento do $13^{\circ}$ salário que seria dia 30 de novembro e 20 dezembro, logo, não havia possibilidade de enquadrá-lo no mapa.

Os procedimentos de tratamento e análise de dados do presente estudo foram realizados por meio da proposta de mapa de associações de ideias, proposta por Mary Jane P. Spink e Helena Lima. Tal quadro nasceu da inquietação das autoras - Spink em especial -, onde está se questionava:

Qual é, por exemplo, o conceito subjacente de evidência que nos possibilita atribuir aos nossos dados o estatuto de representatividade do real? Como nos apropriamos dessas evidências e as traduzimos, de seus estados brutos, para uma nova linguagem - a da interpretação? Qual é, ainda, o estatuto de objetividade que resulta dessa confluência de evidência a interpretação (SPINK; LIMA, 2000, p. 94).

Dividimos a mesma inquietação com as autoras, tendo em vista que ainda não nos resta claro um protocolo a seguir quando se trata de uma análise do discurso; nossa tentativa aqui é buscar um rigor no tratamento dos dados, para que estes nos fomentem um quadro de análise coerente.

Optamos por elaborar 4 mapas de associação de ideias, um para cada elemento do modelo de Serva (1996; 2015). A lógica da construção desses mapas e o seu preenchimento se dá da seguinte maneira: (i) fonte é a indicação de onde provém o conteúdo; (ii) 0 item questão é apenas usado nas entrevistas, pois, nesse tipo de relação e apreensão do empírico existe uma interação, e aqui são transpostas as intervenções do pesquisador/entrevistador; (iii) racionalidade onde está disposta lado a lado as 
racionalidades do tipo instrumental e do tipo substantiva, tendo como subitem as definições de Serva (1996; 2015).

Tal disposição se tornou lógica, uma vez que os dois tipos de racionalidades coexistem; por exemplo, no mesmo contexto, o conteúdo de um documento ou de um discurso pode passar da tônica/ideia instrumental para algo substantivo e vice-versa, de modo a podermos entender a (possível) geração de um conflito.

Tal escolha também se deu, pois assim conseguimos captar as questões valorativas educacionais e suas contradições; (iv) reações/observações onde apontamos momentos de alteração através de uma linguagem não verbal, por exemplo. Essa movimentação é importante para a concepção do mapa de associação de ideias, conforme Spink e Lima nos indicam:

Busca-se organizar os conteúdos a partir dessas categorias, a exemplo das análises de conteúdo, mas procura-se preservar a sequência das falas (evitando, dessa forma, descontextualizar os conteúdos), e identificar os processos de interanimação dialógica a partir da esquematização visual das entrevistas como um todo (ou de trechos selecionados da entrevista). Para a consecução desse objetivo o diálogo é mantido intacto, sem fragmentação, apenas sendo deslocado para as colunas previamente definidas em função dos objetivos da pesquisa (SPINK; LIMA, 2000, p.107, grifo nosso).

A seguir, apresenta-se os mapas elaborados, e um exemplo de uso. 
Quadro 5: Mapa de Associação de Ideias do elemento Valor

\begin{tabular}{|c|c|c|c|c|c|c|c|c|}
\hline \multirow{2}{*}{ Fonte } & \multirow{2}{*}{ Questão } & \multicolumn{3}{|c|}{ Racionalidade Instrumental } & \multicolumn{3}{|c|}{ Racionalidade Substantiva } & $\begin{array}{l}\text { Reações / } \\
\text { Observações }\end{array}$ \\
\hline & & $\begin{array}{l}\text { Utilidade } \\
\text { Dimensão } \\
\text { econômica } \\
\text { considerad } \\
\text { a na base } \\
\text { das } \\
\text { interações } \\
\text { como um } \\
\text { valor } \\
\text { generalizad } \\
\text { o. }\end{array}$ & $\begin{array}{l}\text { Fins } \\
\text { Metas de } \\
\text { natureza } \\
\text { técnica, } \\
\text { econômic } \\
\text { a ou } \\
\text { política } \\
\text { (aumento } \\
\text { de } \\
\text { poder). }\end{array}$ & $\begin{array}{l}\text { Rentabilidade } \\
\text { Medida de } \\
\text { retorno } \\
\text { econômico dos } \\
\text { êxitos e dos } \\
\text { resultados } \\
\text { esperados. }\end{array}$ & $\begin{array}{l}\text { Autorealização } \\
\text { Processos de } \\
\text { concretização do } \\
\text { potencial inato } \\
\text { do indivíduo, } \\
\text { complementados } \\
\text { pela satisfação. }\end{array}$ & $\begin{array}{l}\text { Valores } \\
\text { emancipatórios } \\
\text { Valores de } \\
\text { mudança e } \\
\text { aperfeiçoamento } \\
\text { social nas } \\
\text { direções do bem- } \\
\text { estar coletivo, da } \\
\text { solidariedade, do } \\
\text { respeito à } \\
\text { individualidade, } \\
\text { da liberdade e do } \\
\text { comprometiment } \\
\text { o, presentes nos } \\
\text { indivíduos e no } \\
\text { contexto } \\
\text { normativo do } \\
\text { grupo. }\end{array}$ & $\begin{array}{l}\text { Julgamento } \\
\text { ético } \\
\text { Deliberação } \\
\text { baseadas em } \\
\text { juízo de valor } \\
\text { (bom, mau, } \\
\text { verdadeiro, } \\
\text { falso, certo, } \\
\text { errado etc.), } \\
\text { que se } \\
\text { processa } \\
\text { através do } \\
\text { debate } \\
\text { racional sobre } \\
\text { pretensões de } \\
\text { validez } \\
\text { emitidas } \\
\text { pelos } \\
\text { indivíduos } \\
\text { nas } \\
\text { interações. }\end{array}$ & \\
\hline
\end{tabular}

Fonte: Elaborado pelo autor com base em Serva (1996; 2015) e Spink e Lima (2000).

Quadro 6: Mapa de Associação de Ideias do elemento Tomada de Decisão 


\begin{tabular}{|c|c|c|c|c|c|c|c|}
\hline \multirow{2}{*}{ Fonte } & \multirow{2}{*}{ Questão } & \multicolumn{3}{|c|}{ Racionalidade Instrumental } & \multicolumn{2}{|c|}{ Racionalidade Substantiva } & \multirow{2}{*}{$\begin{array}{l}\text { Reações / } \\
\text { Observações }\end{array}$} \\
\hline & & $\begin{array}{l}\text { Utilidade } \\
\text { Dimensão } \\
\text { econômica } \\
\text { considerad } \\
\text { a na base } \\
\text { das } \\
\text { interações } \\
\text { como um } \\
\text { valor } \\
\text { generalizad } \\
\text { o. }\end{array}$ & $\begin{array}{l}\text { Maximização } \\
\text { recursos } \\
\text { Busca da eficiência } \\
\text { e eficácia máximas, } \\
\text { sem } \\
\text { questionamento } \\
\text { ético, no } \\
\text { tratamento de } \\
\text { recursos } \\
\text { disponíveis, quer } \\
\text { sejam humanos, } \\
\text { materiais, } \\
\text { financeiros, } \\
\text { técnicos, } \\
\text { energéticos, ou } \\
\text { ainda, de tempo. }\end{array}$ & $\begin{array}{l}\text { Cálculo } \\
\text { Projeção } \\
\text { utilitária das } \\
\text { consequências } \\
\text { dos atos } \\
\text { humanos. }\end{array}$ & $\begin{array}{l}\text { Entendimento } \\
\text { Ações pelas quais } \\
\text { se estabelecem } \\
\text { acordos e } \\
\text { consensos } \\
\text { racionais, } \\
\text { mediadas pela } \\
\text { comunicação livre, } \\
\text { e que coordenam } \\
\text { atividades } \\
\text { comuns sob a } \\
\text { égide da } \\
\text { responsabilidade } \\
\text { e satisfação } \\
\text { sociais. }\end{array}$ & $\begin{array}{l}\text { Julgamento ético } \\
\text { Deliberação } \\
\text { baseadas em juízo } \\
\text { de valor (bom, } \\
\text { mau, verdadeiro, } \\
\text { falso, certo, } \\
\text { errado etc.), que } \\
\text { se processa } \\
\text { através do debate } \\
\text { racional sobre } \\
\text { pretensões de } \\
\text { validez emitidas } \\
\text { pelos indivíduos } \\
\text { nas interações. }\end{array}$ & \\
\hline
\end{tabular}

Fonte: Elaborado pelo autor com base em Serva (1996; 2015) e Spink e Lima (2000).

Quadro 7: Mapa de Associação de Ideias do elemento Controle

\begin{tabular}{|c|c|c|c|c|c|c|}
\hline \multirow{2}{*}{ Fonte } & \multirow{2}{*}{ Questão } & \multicolumn{3}{|c|}{ Racionalidade Instrumental } & \multirow{2}{*}{$\begin{array}{c}\text { Racionalidade } \\
\text { Substantiva } \\
\text { Entendimento } \\
\text { Ações pelas quais se } \\
\text { estabelecem acordos e } \\
\text { consensos racionais, } \\
\text { mediadas pela } \\
\text { comunicação livre, e } \\
\text { que coordenam }\end{array}$} & \multirow{2}{*}{$\begin{array}{c}\text { Reações / } \\
\text { Observações }\end{array}$} \\
\hline & & $\begin{array}{l}\text { Desempenho } \\
\text { Desempenho } \\
\text { individual } \\
\text { elevada na } \\
\text { realização de } \\
\text { atividades, }\end{array}$ & $\begin{array}{c}\text { Maximização } \\
\text { recursos } \\
\text { Busca da } \\
\text { eficiência e } \\
\text { eficácia máximas, } \\
\text { sem } \\
\text { questionamento }\end{array}$ & $\begin{array}{c}\text { Estratégia } \\
\text { interpessoal } \\
\text { Influência planejada } \\
\text { sobre outrem, a } \\
\text { partir da antecipação } \\
\text { das reações } \\
\text { prováveis desse }\end{array}$ & & \\
\hline
\end{tabular}




\begin{tabular}{|c|c|c|c|c|c|}
\hline & & $\begin{array}{c}\text { centradas na } \\
\text { utilidade. }\end{array}$ & $\begin{array}{c}\text { ético, no } \\
\text { tratamento de } \\
\text { recursos } \\
\text { disponíveis, quer } \\
\text { sejam humanos, } \\
\text { materiais, } \\
\text { financeiros, } \\
\text { técnicos, } \\
\text { energéticos, ou } \\
\text { ainda, de tempo. }\end{array}$ & \begin{tabular}{|c} 
outrem e \\
determinados \\
estímulos e ações, \\
visando atingir seus \\
pontos fracos.
\end{tabular} & $\begin{array}{c}\text { atividades comuns sob } \\
\text { a égide da } \\
\text { responsabilidade e } \\
\text { satisfação sociais. }\end{array}$ \\
\hline
\end{tabular}

Fonte: Elaborado pelo autor com base em Serva (1996; 2015) e Spink e Lima (2000).

Quadro 8: Mapa de Associação de Ideias do elemento Conflitos

\begin{tabular}{|c|c|c|c|c|c|c|c|c|}
\hline \multirow{2}{*}{ Fonte } & \multirow{2}{*}{ Questão } & \multicolumn{3}{|c|}{ Racionalidade Instrumental } & \multicolumn{3}{|c|}{ Racionalidade Substantiva } & $\begin{array}{c}\text { Reações / } \\
\text { Observações }\end{array}$ \\
\hline & & $\begin{array}{c}\text { Cálculo } \\
\text { Projeção } \\
\text { utilitária das } \\
\text { consequências } \\
\text { dos atos } \\
\text { humanos. }\end{array}$ & $\begin{array}{c}\text { Fins } \\
\text { Metas de } \\
\text { natureza } \\
\text { técnica, } \\
\text { econômica } \\
\text { ou política } \\
\text { (aumento } \\
\text { de poder). }\end{array}$ & $\begin{array}{c}\text { Estratégia } \\
\text { interpessoal } \\
\text { Influência } \\
\text { planejada } \\
\text { sobre outrem, } \\
\text { a partir da } \\
\text { antecipação } \\
\text { das reações } \\
\text { prováveis } \\
\text { desse outrem } \\
\text { e } \\
\text { determinados } \\
\text { estímulos e } \\
\text { ações, visando }\end{array}$ & $\begin{array}{c}\text { Autonomia } \\
\text { Condição } \\
\text { plena dos } \\
\text { indivíduos } \\
\text { para poderem } \\
\text { agir e } \\
\text { expressarem- } \\
\text { se livremente } \\
\text { nas } \\
\text { interações. }\end{array}$ & $\begin{array}{l}\text { Autenticidade } \\
\text { Integridade, } \\
\text { honestidade, e } \\
\text { franqueza dos } \\
\text { indivíduos nas } \\
\text { interações. }\end{array}$ & $\begin{array}{c}\text { Julgamento ético } \\
\text { Deliberação } \\
\text { baseadas em juízo } \\
\text { de valor (bom, } \\
\text { mau, verdadeiro, } \\
\text { falso, certo, } \\
\text { errado etc.), que } \\
\text { se processa } \\
\text { através do debate } \\
\text { racional sobre } \\
\text { pretensões de } \\
\text { validez emitidas } \\
\text { pelos indivíduos } \\
\text { nas interações. }\end{array}$ & \\
\hline
\end{tabular}




\begin{tabular}{|l|l|l|l|l|l|l|l|}
\hline & & & $\begin{array}{c}\text { atingir seus } \\
\text { pontos fracos. }\end{array}$ & & & \\
\hline
\end{tabular}

Fonte: Elaborado pelo autor com base em Serva (1996; 2015) e Spink e Lima (2000). 
Por exemplo, na figura 2, extraída do mapa de associação de ideias do elemento Controle, apreendido de uma entrevista -, onde foi possível captar a movimentação de discurso que saiu do substantivo e caiu no instrumental, e este contradisse os valores educacionais. Já na figura 3, ao colocar o conteúdo de uma ata no mapa de associação de ideias de decisão, nós captamos uma alteração de discurso dentro ainda da racionalidade substantiva. Por fim, na figura 4, na transposição das notas de campo de uma observação para o mapa de associação de ideias de valores, a alternância do discurso se manteve dentro da racionalidade instrumental.

Figura 2: Exemplo da movimentação e composição do mapa de associação de ideias do substantivo para o instrumental

\begin{tabular}{|c|c|c|c|c|c|c|}
\hline \multirow[b]{2}{*}{ Fonte } & \multirow[b]{2}{*}{ Questão } & \multicolumn{3}{|c|}{ Racionalidade Instrumental } & \multirow{2}{*}{\begin{tabular}{|c|} 
Racionalidade Substantiva \\
Entendimento
\end{tabular}} & \multirow[b]{2}{*}{ Reações / Observaçōes } \\
\hline & & $\begin{array}{c}\text { Desempe } \\
\text { nho }\end{array}$ & $\begin{array}{c}\text { Maximizaçã } \\
\text { o recursos }\end{array}$ & $\begin{array}{c}\text { Estratégia } \\
\text { interpessoal }\end{array}$ & & \\
\hline & $\begin{array}{ll}\text { isso } & \text { é } \\
\text { passado } & \text { a } \\
\text { diante. } & \end{array}$ & & $\begin{array}{l}\text { a não ser } \\
\text { que seja } \\
\text { uma } \\
\text { situação que } \\
\text { entenda que } \\
\text { possa mudar } \\
\text { um contexto } \\
\text { ou provocar } \\
\text { uma } \\
\text { situação de } \\
\text { mudança }\end{array}$ & & $\begin{array}{l}\text { issa é passado isso é } \\
\text { passado paratodos os níveis } \\
\text { eu faço questão de levar } \\
\text { essa situação aos demais } \\
\text { níveis e distribuir autonomia } \\
\text { também aos demais níveis as } \\
\text { pró-reitoras e respeitar a } \\
\text { posições }\end{array}$ & \\
\hline
\end{tabular}

Fonte: Elaborado pelos autores 
RBEQ:

Estudos Organizacionais

\section{Elizeu Alves e Samir Adamoglu}

Relações entre Racionalidades na Gestão Organizacional: Um Estudo de Caso em uma Instituição de Ensino Superior (Ies) Privada em Curitiba

Figura 3: Exemplo da movimentação e composição do mapa de associação de ideias dentro do substantivo

\begin{tabular}{|c|c|c|c|c|c|c|c|}
\hline \multirow{2}{*}{ Fonte } & \multirow{2}{*}{ Questão } & \multicolumn{3}{|c|}{ Racionalidade Instrumental } & \multicolumn{2}{|c|}{ Racionalidade Substantiva } & \multirow{2}{*}{$\begin{array}{c}\text { Reações / } \\
\text { Observações }\end{array}$} \\
\hline & & Utilidade & $\begin{array}{l}\text { Maximizaçã } \\
\text { o recursos }\end{array}$ & Cálculo & Entendimento & Julgamento ético & \\
\hline ATCP01 & & & & & $\begin{array}{l}\text { Os coordenadores } \\
\text { apresentam as suas } \\
\text { propostas para } \\
\text { alteração da grade e } \\
\text { estas são postas para } \\
\text { votação. }\end{array}$ & $\begin{array}{l}\text { O próximo item da } \\
\text { auta refere-se ao } \\
\text { lome Social } \\
\text { versus Nome Civil, } \\
\text { onde a chefe de } \\
\text { gabinete, onde } \\
\text { esta afirma que a }\end{array}$ & \\
\hline
\end{tabular}

Fonte: Elaborado pelos autores 
Figura 4: Exemplo da movimentação e composição do mapa de associação de ideias dentro do instrumental

\begin{tabular}{|c|c|c|c|c|c|c|c|c|}
\hline \multirow[b]{2}{*}{ Fonte } & \multirow[b]{2}{*}{ Questão } & \multicolumn{3}{|c|}{ Racionalidade Instrumental } & \multicolumn{3}{|c|}{ Racionalidade Substantiva } & \multirow[b]{2}{*}{$\begin{array}{c}\text { Reações / } \\
\text { Observaçõ } \\
\text { es }\end{array}$} \\
\hline & & Utilidade & Fins & Rentabilidade & $\begin{array}{c}\text { Autorealizą̧ } \\
\text { ão }\end{array}$ & $\begin{array}{c}\text { Valores } \\
\text { emancipatório } \\
\text { s }\end{array}$ & $\begin{array}{l}\text { Julgamento } \\
\text { ético }\end{array}$ & \\
\hline & & & $\begin{array}{l}\text { a } \\
\text { Continusndp } \\
\text { ele relat } \\
\text { que no nosso } \\
\text { caso, } \\
\text { modemos } \\
\text { nossors } \\
\text { eficiêncis }\end{array}$ & $\begin{array}{l}\text { esse } \\
\text { crescimento é } \\
\text { menor do que } \\
\text { comparado } \\
\text { com o gnos } \\
\text { snteriores, } \\
\text { porém ele é } \\
\text { satisfatório. } \\
\text { Sem contar no } \\
\text { programs que } \\
\text { com esse } \\
\text { crescimento } \\
\text { chegou-se } \\
\text { perto do ebitds } \\
\text { espergoj de } \\
25 \%\end{array}$ & & & & \\
\hline
\end{tabular}

Fonte: Elaborado pelos autores

O mapa de associação de ideias de valores conclui-se com 253 páginas; o de tomada de decisão com 98 páginas; o de controle com 62 páginas; e o de conflitos com 115 páginas.

Assim, 169 documentos foram analisados, distribuídos em 67 comunicados internos (CI), 11 manuais comportamentais (MN), 79 resoluções administrativasacadêmicas (RS), 5 propósitos organizacionais (PO) e 7 atas de reuniões (AT). Desses, utilizamos para compor os mapas 10 comunicados internos, 6 manuais comportamentais, 17 resoluções administrativas-acadêmicas, 3 propósitos organizacionais e 4 atas de reuniões, juntamente com as 12 entrevistas e apenas 6 dos 7 eventos (observação participante) observados, pois apenas esses se enquadravam no padrão de racionalidade instrumental e substantivo que apresentamos na DC. Essa distribuição de fontes está descrita no quadro 25 a seguir. 
Quadro 9 - Distribuição de fontes na elaboração dos mapas de associação de ideias

\begin{tabular}{|l|l|}
\hline \multicolumn{1}{|c|}{ Nome do Mapa } & \multicolumn{1}{c|}{ Fontes que o compõe } \\
\hline Valores & E1, E2, E3, E4, E5, E6, E7, E8, E9, E10, E11, E12, EV3, EV4, EV5, \\
& EV6, EV7, RS1, RS2, RS3, RS5, RS6, RS10, RS11, RS13, RS37, \\
& RS45, RS88, CI3, CI4, CI11, CI15, CI18, CI26, CI44, CI52, CI67, \\
& MN1, MN2, MN5, MN6, MN7, MN10 e P06. Total: 48 fontes \\
\hline Conflitos & E1, E2, E3, E4, E5, E6, E7, E8, E9, E10, E11, E12, EV1, EV5, RS23, \\
& RS55, MN1, MN2, MN5, MN7, P01 e P06. Total: 22 fontes \\
\hline Controle & E1, E2, E3, E4, E5, E6, E7, E8, E9, E10, E11, E12, EV3, EV6, RS6, \\
& RS33, RS55, CI48, MN1, MN2, MN5, MN6, P04, P06 e ATCL2. \\
& Total: 25 fontes \\
\hline Tomada de Decisão & E1, E2, E3, E4, E5, E6, E7, E8, E10, E11, E12, EV3, RS1, RS2, RS3, \\
& RS4, RS5, RS7, RS12, RS13, RS33, CI26, P01, P02, P06, ATCP1 e \\
& ATCP2. Total: 27 fontes \\
\hline
\end{tabular}

Para se analisar tais mapas, buscou-se auferir a intensidade do aparecimento dos textos das racionalidades, utilizando como método de apoio a contagem de quantos pontos eram discutidos nas categorias de racionalidade instrumental e quantos eram na substantiva dentro dos quatro mapas de associação de ideias, tal contagem foi realizada manualmente no material impresso. Com isso, teríamos alguns índices que nos trariam as intensidades que poderíamos trabalhar sobre elas no intuito de entender incialmente em que nível se daria essa relação de racionalidade na prática discursiva organizacional e, a partir dela, conceber quais os níveis de conflitos dessa relação, e como estes se solucionam. A tabela 2 apresenta os principais pontos revelados pelos mapas de associação de ideias.

Tabela 2 - Distribuição de pontos de racionalidades dentro dos mapas de associações de ideias

\begin{tabular}{|c|c|c|c|c|}
\hline Mapa & Tipo de Fonte & $\begin{array}{c}\text { Pontos } \\
\text { instrumentais }\end{array}$ & $\begin{array}{c}\text { Pontos } \\
\text { Substantivos } \\
\end{array}$ & Total \\
\hline \multirow[b]{2}{*}{ Valores } & Primária & 60 & 41 & 101 \\
\hline & Secundária & 14 & 50 & 64 \\
\hline \multicolumn{2}{|r|}{ Total } & 74 & 91 & 165 \\
\hline \multirow[b]{2}{*}{ Conflitos } & Primária & 35 & 36 & 71 \\
\hline & Secundária & 2 & 13 & 15 \\
\hline
\end{tabular}




\begin{tabular}{|c|c|c|c|c|}
\hline & Total & 37 & 49 & 86 \\
\hline \multirow[b]{2}{*}{ Controle } & Primária & 17 & 16 & 33 \\
\hline & Secundária & 9 & 6 & 15 \\
\hline \multicolumn{2}{|r|}{ Total } & 26 & 22 & 48 \\
\hline \multirow{2}{*}{$\begin{array}{l}\text { Tomada de } \\
\text { decisão }\end{array}$} & Primária & 38 & 24 & 62 \\
\hline & Secundária & 6 & 13 & 19 \\
\hline \multicolumn{2}{|r|}{ Total } & 44 & 37 & 81 \\
\hline T. GERAL & & 181 & 199 & 380 \\
\hline
\end{tabular}

Fonte: Os autores

De modo a fazer uma análise inicial, vamos discutir os resultados apresentado em tal quadro, onde mais adiante avançaremos em uma análise mais criteriosa, buscando evidenciar como se dá a relação de racionalidades captada no material empírico coletado.

$\mathrm{Na}$ análise de modo geral, entendendo que cada ponto de racionalidade instrumental irá anular um ponto de racionalidade substantiva, teremos então 18 pontos a mais dentro dos 380 pontos auferidos; neste sentido, de modo geral, identifica-se uma predominância da racionalidade substantiva, principalmente em consideração a proximidade dos pontos instrumentais.

Para o elemento de racionalidade 'Valor', dentro dos 165 pontos de racionalidades, temos 17 pontos a mais de uma predominância da racionalidade substantiva; porém, essa predominância se deu pelas fontes secundárias, sendo para isso válido o raciocínio de Yin (2005), quando este relata que toda fonte impressa passa por um crivo (um filtro) antes de ser publicada, não devendo ser tratada como uma constatação definitiva. Tal constatação será analisada mais adiante.

Para o elemento de racionalidade 'Conflitos', dentro dos 86 pontos de racionalidades, temos 12 pontos a mais de uma predominância da racionalidade substantiva e, diferentemente do mapa de associação de ideias para 'Valores', tal predominância já aparecia nas fontes primárias, onde a racionalidade substantiva obtivera 1 (um) ponto a mais que a instrumental, fato esse vindo a se confirmar pelas fontes secundárias.

No caso do elemento de racionalidade 'Controle', temos a predominância de uma racionalidade instrumental, onde está possui 4 (quatro) pontos a mais de intenção dentro dos 48 pontos de racionalidades; chamando atenção de que há um aparente equilíbrio, e a virada de intensidade da racionalidade instrumental sob a substantiva se deu nas fontes secundárias. 
Dentro da racionalidade 'Tomada de Decisão', temos 81 apontamentos de racionalidade, onde há uma predominância da racionalidade instrumental, esta possuindo 7 (sete) a mais; a predominância já vinha desde as fontes primárias, e a diferença da substantiva foi em fontes secundárias.

Essa análise inicial nos deu subsídio para pré-identificarmos alguns conflitos na relação de racionalidade no discurso organizacional onde, em inúmeros casos, o que está registrado formalmente não é seguido pelo discurso das fontes primárias. Assim, já encontramos algumas contradições, as quais a partir deste momento aprofundaremos em análises iniciais, buscando desvendar como se encaminham as resoluções de tais conflitos, principalmente no tocante ao poder.

Em estágio seguinte, empregou-se a Análise Crítica do Discurso (ACD), a fim de identificar como ocorrem os conflitos entre as racionalidades instrumental e substantiva na pratica discursiva organizacional, e como incide o uso do poder para solucionar impasses gerados por tais circunstâncias.

Fairclough (2001) entende o discurso como uma prática social reprodutora e transformadora de realidades sociais, e o sujeito da linguagem (a partir de uma perspectiva psicossocial), tanto propenso ao moldamento ideológico e linguístico quanto agindo como transformador de suas próprias práticas discursivas, contestando e reestruturando a dominação e as formações ideológicas socialmente empreendidas em seus discursos. Dessa maneira, o sujeito ora se conforma às formações discursivas/sociais que o compõem, ora resiste a elas. Com isso, ele a ressignifica e a reconfigura. Logo, a língua é uma atividade dialética que molda a sociedade e é moldada por ela.

Fairclough (2001) completa salientando que as práticas discursivas - ao serem produzidas e reproduzidas -, se naturalizam e vão ganhando aceitação social, tornando-se hegemônicas. Cada ação realizada na dimensão social configura um 'texto', e os 'discursos' que são praticados socialmente são, por sua vez, compostos 
de 'textos', que se vinculam interativamente (em retrospecto, em contemporaneidade, e em projeção) entre si, configurando, portanto, conjuntos de

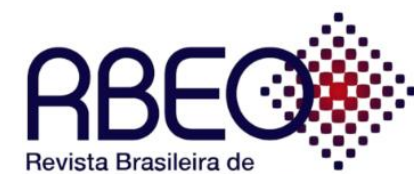

Estudos
Elizeu Alves e Samir Adamoglu

Relações entre Racionalidades na Gestão Organizacional: Um Estudo de Caso em uma Instituição de Ensino Superior (Ies) Privada em Curitiba

textos conectos - os 'intertextos'. Assim, devemos entender a concepção tridimensional do discurso e sua intertextualidade no que se refere a 'pratica discursiva'.

Entendemos, então, que a contribuição de Fairclough para o presente estudo é a capacidade da sua analítica em lançar luz a construção do discurso, principalmente o adotado no uso do poder, afinal, para Fairclough (2001), a pratica discursiva recorre a contratos que vão naturalizar as relações de poder em suas próprias convenções. Assim, tal procedimento de análise do material empírico guarda conformidade com as questões centrais do presente estudo.

Neste estudo, os gestores organizacionais foram categorizados em 3 (três) polos, onde utilizamos como critério o nível de proximidade do gestor com a mantenedora - leia-se, a aproximação para com o diretor presidente e o diretor executivo da organização mantenedora. Os atores que se caracterizavam por sustentar essa proximidade foram classificados na categoria rotulada 'elite organizacional', (salientando que esse rótulo não almejou carregar classificação de valores, mas, indicar que apenas um específico grupo possui tal grau de proximidade).

Os gestores que fazem parte deste grupo, mas que possuem pouco tempo de empresa (menos de um ano), foram classificados como 'elite gerencial secundária'; tal distinção se fez necessária para entendermos até que ponto esse envolvimento de proximidade se dá de forma espontânea, pois, a tendência é uma grande aproximação de início, para fins de obter conhecimento da empresa. Por fim, a última classificação realizada remeteu ao rótulo 'baixa gestão', onde se enquadraram os gestores que possuem sua relação com a mantenedora de forma intermediada pelo grupo de profissionais pertencentes à categoria 'elite organizacional'. 


\section{ANÁLISE DOS DADOS}

Para se analisar tais mapas, buscou-se auferir a intensidade do aparecimento dos textos das racionalidades, utilizando como método de apoio a contagem de quantos pontos eram discutidos nas categorias de racionalidade instrumental e quantos eram na substantiva dentro dos quatro mapas de associação de ideias, tal contagem foi realizada manualmente no material impresso. Com isso, teríamos alguns índices que nos trariam as intensidades que poderíamos trabalhar sobre elas no intuito de entender incialmente em que nível se daria essa relação de racionalidade na prática discursiva organizacional e, a partir dela, conceber quais os níveis de conflitos dessa relação, e como estes se solucionam.

$\mathrm{Na}$ análise de modo geral, entendendo que cada ponto de racionalidade instrumental irá anular um ponto de racionalidade substantiva, teremos então 18 pontos a mais dentro dos 380 pontos auferidos; neste sentido, de modo geral, identifica-se uma predominância da racionalidade substantiva, principalmente em consideração a proximidade dos pontos instrumentais.

Essa análise inicial nos deu subsídio para pré-identificarmos alguns conflitos na relação de racionalidade no discurso organizacional onde, em inúmeros casos, o que está registrado formalmente não é seguido pelo discurso das fontes primárias. Assim, já encontramos algumas contradições.

De modo a prosseguir na análise do caso, precisamos resgatar e entender que as organizações em estudo são interdependentes, ou seja, uma necessita de outra para existir - sendo a mantenedora (o Grupo Alpha) a organização dotada de caráter jurídico e econômico, e a organização mantida (a IES Beta) aquela que possui em sua característica a realização das atividades acadêmicas. Neste sentido, devemos nos voltar ao contexto de ambas, e entender que ambas se influenciam, e em muitos momentos agem juntas para atingir os objetivos traçados pela mantenedora. 
Assim, quando buscamos identificar como se manifestam as racionalidades, a apresentação dos resultados nos confere um panorama do viés de racionalidade instrumental para onde pende a mantenedora.

RAC. INST. Então essa relação administrativa e pedagógica ainda não é muito bem imbricada. Geralmente as coisas acontecem a partir dos princípios administrativos e depois a gente vê com isso aqui no pedagógico ou se pensa no pedagógico sem se verificar qual seria $o$ respaldo administrativo. Para isso, daí depois a gente tenta acertar o que dê primeiro um pensa depois o outro pensa e depois a gente acerta, mas acho que essa relação mais harmoniosa não existe. (Entrevistado 1).

Tal argumento do entrevistado 1 mostra a contradição e inversão dos aspectos valorativos educacionais, onde em primeiro momento o que se sobressaí é a lógica econômica do consumo e satisfação, que representa o viés instrumental sobrepondo-se sobre a questão pedagógica do ensino-aprendizagem.

Isso, levando em consideração a postura do entrevistado, onde este se mostrava em certo ponto receoso, com os questionamentos que figuravam na visão de cálculo utilitário.

RAC. INST. Ela sempre nos olhava nos olhos e sempre sorria quando fazíamos perguntas sobre questões polêmicas como lucro, estrutura de curso, etc. E1 se manteve calma e constante em toda a entrevista. (Entrevista 1)

A manifestação de uma postura mais inclinada para a racionalidade instrumental na organização mantenedora se deu em todas as entrevistas, em alguns documentos e nas observações de eventos, sempre quando se envolvia a questão financeira, e em alguns casos, na questão de resolução de conflitos.

RAC. INST. E, a partir de 2012, começou a se estabelecer, pela Mantenedora, então, assim, solicitações, e daí, em cima das solicitações, as cobranças... (Entrevistado 2)

RAC. INST. Hum, eu vejo que o foco aqui é o aluno né, eu percebo isso né, talvez não o funcionário, mas o foco é o aluno que é o cliente final, então eu vejo nesse sentido o que precisar de investimento pelo menos né a impressão que tem é que está aberto. Ah, eu preciso fazer uma visita, preciso fazer tal coisa, lógico tem todo um processo de aprovação, mas tem a disponibilidade. (Entrevistado 4) 
RAC. INST. Para dar conta da sua missão institucional e atingir as metas propostas na visão institucional IES Beta tem como objetivo geral ministrar, nas modalidades presencial e a distância, cursos que ofereçam

estreita articulação com o setor produtivo, objetivando atender às demandas de qualificação profissional exigidas pelo mercado de trabalho. (Propósitos Organizacionais 2)

O que nos chama atenção em tais exemplos é a associação de que o aluno tem sua valorização pelo fato de ser um cliente dentro de uma relação transacional (quase que majoritariamente 'comercial') a qual o Grupo Alpha sustenta por estar envolto ao mercado de trabalho, e não a partir de um viés mais voltado ao elemento humanista/subjetivista do aluno qual se encontra em busca de uma capacitação profissional, sim, mas também de uma formação emancipatória para a sociedade, que o desenvolva enquanto ator na sociedade civil. Nesse ponto, temos a clara contradição da lógica substantiva de uma IES como entidade social para uma IES mercantilista, onde esta apresenta o aluno como um cliente, a educação como mercadoria, e o professor como vendedor.

Quando buscamos a manifestação de racionalidades na IES Beta, nos deparamos no quadro onde os gestores principais E2 e E5 (estes mais próximos aos mantenedores) promulgam, em sua discursividade, uma total inclinação ao elemento substantivo - sendo este amparado pelos documentos -; contudo, a sensação que nos é passada por tais fontes não chega em sua totalidade aos demais entrevistados e, em certos momentos, contradizem algumas passagens descritas por eles. Do lado dos gestores principais, por exemplo, na questão de valores, podemos destacar:

RAC. SUB. Sim. Eles \{os valores\} foram amplamente discutidos em reunião de Diretoria. É... e essa Diretoria é composta por membros de..., da maioria das Mantidas. E... E cada 1 (um) participou e levou bastante tempo. (Entrevistado 1)

RAC. SUB. Eles \{valores\} foram estabelecidos pela mantenedora em conjunto com a diretoria \{da mantida\} e demais setores que participaram de um debate, de uma discussão bastante prorrogada. (Entrevistado 5) RAC. SUB. Um grande exemplo disso, não vou entrar em detalhes, nem nomes, mas nós demitimos um professor de um curso, agora recentemente a partir de uma sindicância feita internamente respeitando um dos valores máximos nosso que é justamente a questão do respeito do ser humano, e esse professor faltou com respeito tanto a funcionários 
quanto a alunos, fizemos a sindicância constatamos a real situação e ele foi demitido. (Entrevistado 5)

RAC. SUB. Este código de conduta foi concebido especificamente para enfatizar os princípios pelos quais a instituição conduz as relações com seus colaboradores, professores, clientes, alunos, fornecedores, parceiros de negócios, visitantes e a sociedade em geral. Este código de conduta aplica-se aos administradores, executivos, professores e colaboradores de todos os níveis funcionais do Grupo Alpha e IES Beta. (Manual 1)

RAC. SUB. Nós, do Grupo Alpha entendemos que trabalhar com e pela educação e uma das atividades mais nobres. E nobre porque transforma de verdade a vida das pessoas. (Manual 2)

No trecho do manual 2 a seguir temos a proposta de ação de uma coordenação pedagógica, porém ao confrontar tal afirmação com o relato do entrevistado 7, já começamos a identificar a manifestação e materialização de conflitos na relação das organizações.

RAC. SUB. A Coordenação Pedagógica presta assessoria didáticopedagógica as diversas atividades desenvolvidas na IES, visando a constante melhoria do processo ensino-aprendizagem. Para isso, assessora os coordenadores de curso, elabora e implementa propostas de formação continuada para os professores e os orienta nas questões pedagógicas. (Manual 2)

RAC. INST. Mas quando você vai ver na operação \{o trabalho da coordenação pedagógica\} entra em contradição.... é as coisas não são bem assim.. Então.... acho que não tá muito claro isso e não sei se tem como medir, não sei. A gente não tem é muita clareza de qual é de verdade o caminho da instituição, porque daí assim, ok, então vamos criar esses cursos ou essas ações, daqui a pouco não sei bem por qual a razão mudam, e então não é mais o curso que era pra ser desse jeito vai ser do outro e da mesma forma a gente fica sabendo por acaso porque a gente é fuçador e aí fica difícil você manter um trabalho mais coeso, mais coerente, a gente acaba tendo que fazer tapar buraco catar ponta de lençol amarrar e aí você não consegue trabalhar otimamente. (Entrevistado 7)

Esse tipo de conflito de racionalidade nos é sempre salientado quando cruzamos as fontes de dados do estudo, sobretudo quando, por exemplo, analisamos um documento e fomos tenta-lo enxergar acontecendo empiricamente em um evento, como uma reunião. Algo dessa sorte que nos chamou bastante a atenção foi o evento 7, onde o primeiro ato de fala do diretor presidente foi relatar números econômicos. 
RAC. INST. O Diretor Presidente que começou saudando a todos, principalmente a nossa contadora, e disse que "o ano de 2014 foi um ano difícil, pois teve copa e eleição e o crescimento do Brasil chegou a 0,5\% e o \{grupo alpha\} chegou a 10\% de crescimento está próximo a chegar aos $15 \%$ sendo que esse crescimento é menor do que comparado com os anos anteriores, porém ele é satisfatório. Sem contar no programa que com esse crescimento chegou-se perto do obtida esperado de 25\%". (Evento 7)

E logo em seguida já traçou a grande métrica para 2015:

RAC. INST. Continuando, ele relatou que no nosso caso, "podemos melhorar a nossa eficiência e com ajuda dos funcionários nós podemos mudar e melhorar a nossa que eficiência e que com a ajuda de vocês, nós conseguiremos bater nossa grande meta no ano que vem nosso foco para 2015 será o ano da evasão, o foco vai ser a evasão, pois se reduzir a evasão teremos um diferencial competitivo. Temos que reduzir em 10\%, mesmo que seja de 5\% nós seguiremos para ter mais esse diferencial competitivo". Caminhou à frente e disse que "só conseguiremos isso respeitando o aluno, porque nós ofertamos a educação de alto nível e agora cabe ao respeito ao aluno, dando um sorriso pra ele, uma boa atenção, né, temos que cuidar muito bem dos nossos clientes". (Evento 7)

Neste sentido, novamente temos o aluno enquanto 'cliente', uma visão mercantilista de cunho instrumental, onde o aluno é visto como o cliente que adquire a mercadoria apenas para sua ascensão econômica, e não um instrumento de reflexão e visão social. Nessa fala inicial do diretor presidente registrada no evento 7 não foi mencionado nenhum índice acadêmico - como as notas atribuídas pelo MEC que 'traduzem' qualidade no ensino. Essa foi a tônica de toda a reunião, como podemos ver na fala do diretor executivo.

RAC. INST. O diretor executivo pegou o microfone e falou o quanto é estratégico se investir em tratamento e o quanto essa empresa investe na qualificação de seus funcionários para que seja oferecido o melhor serviço para seus clientes, o que é atividade fim dos negócios. (Evento 7)

Esse conteúdo registrado em nota de campo referente ao evento 7 difere, por exemplo, do Propósito Organizacional 1 e 2 que constam nos documentos Projeto Pedagógico do Curso Superior - Presencial, Projeto de Desenvolvimento Institucional e Projeto Pedagógico Institucional coletados: 
RAC. SUB. Conforme consta na missão da IES, a responsabilidade social é um dos vetores que orienta suas políticas e ações. Ao entender a educação como um direito de todo cidadão, a instituição abre a possibilidade de utilizá-la na fundamentação de sua política de responsabilidade social, fazendo a fusão da formação técnica, ética e humana e da oferta de um ensino de qualidade a todos, com princípios como a inclusão social e a diversidade étnica e cultural, sem distinção de classe, gênero, etnia ou religião. (Propósito Organizacional 1)

RAC. SUB. A missão da Beta traduz-se num projeto de ensino capaz de oferecer acesso aos conhecimentos científicos e tecnológicos, de forma democrática, compreendendo o espaço universitário como um ambiente de transformação social e de difusão de valores humanos. Do ponto de vista de sua inserção social, leva-se em conta que na atual sociedade informacional as questões da homogeneização e do consequente empobrecimento da diversidade cultural têm sido permanentemente colocadas em pauta. (Propósito Organizacional 2)

Conforme apresentado, o arranjo estrutural das organizações dá margens a conflitos racionais. Demonstrada sua manifestação em ambas as organizações e a percepção acerca de conflitos oriundos das duas organizações, parte-se agora para uma identificação de textos que, em sua intertextualidade discursiva, serão base para uma análise crítica do discurso de modo a trazer luz a sua manifestação, possibilitando assim entender de que modo o poder é utilizado na mediação de tais conflitos. Antes de se iniciar, resgatamos a afirmação de Leitch e Palmer:

\begin{abstract}
ACD pode primeiro ser vista como um ramo de estudos críticos em termos mais gerais e, como tal, tem um foco em problemas sociais e dinâmicas de poder associadas, incluindo sistemas de dominação e instâncias de resistências (LEITCH; PALMER, 2010, p. 1194, tradução nossa)
\end{abstract}

Dessa forma, a análise a seguir apresentada busca verificar como as práticas linguísticas, discursivas e sociais se inter-relacionam nas estruturas socialmente alicerçadas em práticas ideológicas. Nesse sentido, o uso de linguagem para a ACD é moldado no social, não no individual. Fairclough (2001, p. 90) salienta "o uso de linguagem como forma de prática social", e isso compreende tomar o discurso como uma forma de ação e assim admitir que sua relação com a estrutura social seja dialética. Dessa forma, o social constrói o discurso e é por ele construído. 
Consideramos como 'texto' todas as ações que se estruturam para indicar a condição que dá base para a racionalidade, e seu confronto com a contradição, uma vez que, segundo Fairclough (2001), a forma como um texto é produzido e interpretado dependem da natureza da prática sociocultural que integra o discurso (incluindo a sua relação com hegemonias já existentes); ou seja: a natureza da prática discursiva molda a produção de um 'texto', deixando sinais nas suas características superficiais. Com isso, temos que em quase sua totalidade, as fontes documentais nos mostram uma racionalidade substantiva que em muitas situações não ecoam nas demais fontes, principalmente nos eventos observados, ou como relata o entrevistado 1 :

RAC. INST. Olha, uma resposta indelicada, porque assim, nesse eu confesso que necessariamente é uma empresa, portanto não tem como não lidar com as relações de lucro, mas eu diria que se essa decisão pelo lucro, eles fazem isso de uma forma que não faça parecer entendeu \{Risos\}. (Entrevistado 1)

A sensação relatada no excerto acima vem de parte da mantenedora, onde o entrevistado 1 relata que o próprio gestor principal da mantida entra nesse jogo e reproduz tal lógica. Sendo que a sensação do entrevistado 1 também é percebida por outros entrevistados, e foi observado pelo pesquisador ao longo de eventos.

RAC. INST. Eu acho que o próprio Reitor tem por essência essa
preocupação \{com a qualidade de ensino\} aí ele disfarça um pouco, mas
eu eu diria assim, o lucro está efetivamente por trás, mas eu diria que eles
fazem esse processo de uma maneira que é para deixar transparecer essa
outra preocupação \{qualidade de ensino\} entendeu. (Entrevistado 1)
RAC. INST. O que vai pesar sempre é o financeiro, mas eu curiosamente já
estou aqui muito pouco tempo, mas já consigo, não sei por que distinguir
claramente uma distinção, assim ao meu olhar bem claro. De que o dono
da instituição tem ainda uma preocupação com aspecto pelo menos na sua
fala, né. (Entrevistado 8)

A intertextualidade entre os excertos acima se manifesta em falas, documentos e atitudes, pois, Fairclough (2001, p. 133) descreve que "não pode haver enunciado que de uma maneira ou de outra não reatualize outros", e Leitch e Palmer (2010, p. 1197, tradução nossa) explicam que "o contexto dentro deste modelo 
amplamente adotado consiste em práticas discursivas, incluindo a produção, distribuição e interpretação de textos e práticas sociais".

A intertextualidade de tais textos alicerça a construção de uma prática discursiva na qual a racionalidade instrumental se sobressai nas práticas organizacionais, de forma velada, onde os textos de ações documentais nos mostram um panorama mais substantivo, onde há autonomia para os atores, com uma aparente resolução de conflitos baseada em um debate racional. Porém esse é apenas um discurso de manipulação rodeado de um uso de poder simbólico.

Por conta de sua ligação direta com a mantenedora, os entrevistados 2 e 5 reproduzem e fomentam a distribuição e consumo do discurso de uma gestão pautada por um viés instrumental, de forma que os que estão sujeitos a tal distribuição reproduzem tal discurso, parecendo natural às práticas organizacionais. Por exemplo, a análise dos dados coletados no estudo nos demonstrou a questão da autonomia; porém, vemos que tal autonomia lhe é retirada se a decisão for para algo estratégico à organização, sendo que em muitos casos, os documentos que possuem o viés da racionalidade substantiva são os que garantem as decisões instrumentais, e a elas legitimam. Para isso, inclusive usa-se de elementos externos, dentro de uma estrutura social, pensando na questão da educação superior que é regulada pelo MEC, onde para manter esse mascaramento da racionalidade instrumental, apoia-se em questões maiores para dar legitimidade e ter $\mathrm{o}$ aceite de tais atos.

RAC. SUB. Eu tenho total autonomia, eu aqui faço o que eu quiser, \{risos\} essa é a única vantagem que eu acho que tem nessa bagunça toda, que o que eu quero fazer na minha unidade eu faz. (Entrevistado 10)

RAC. INST. Eles precisam estar convencidos de que aquela decisão é a correta, mas as decisões que são muito pontuais. Existem às decisões que precisam ser pontuais por uma questão de agilidade frente ao próprio mercado a própria concorrência. (Entrevistado 5)

RAC. INST. Quando eu entrei aqui, as pessoas me disseram assim, "o lema da IES Beta é igual o da Band News \{Rádio FM de notícias\}, em 20 minutos, tudo pode mudar". Achei que era uma brincadeira, mas é a pura verdade. (Entrevistado 6) 
RAC. INST. A coordenadora pedagógica inicia dizendo que todos sabem que tal avaliação é determinação da reitoria e que ela não iria entrar em detalhes. (Evento 3)

RAC. INST. Nós somos uma instituição autorizada pelo ministério da educação, credenciada pelo ministério da educação, consequentemente acha implícito nesse processo uma serie de é aspectos de valores que devem ser sobre tudo e acima de tudo observados principalmente a partir do respeito da legislação oficial ai a partir das definições do ministério e demais órgãos. (Entrevistado 5)

Com isso, temos que a estrutura organizacional com sua margem para o conflito de racionalidades tem o poder como mediador de conflitos, e o uso desse poder se dá de forma simbólica, onde os sujeitos ao poder são influenciados a acreditar que tais decisões são para o alcance de objetivos maiores, ou em cumprimento de métricas propostas pelo MEC, sendo que estes são interpretados pela elite organizacional e não há resistência a eles por parte de quem está à mercê do poder.

Por legítimo, entendemos o uso do poder simbólico em algumas decisões (que configuram textos) que, mesmo que pautadas em uma racionalidade instrumental - e contra a vontade de muitos - se vale para manter a ordem organizacional e dar fluidez aos processos; tal simbolismo se dá como o poder de nomeação na qual o gestor da mantida está investido.

Por fim, o mascaramento de uma racionalidade instrumental permeando os processos organizacionais torna-se uma prática por meio de um discurso que é construído por meio de um uso de poder simbólico e que, dessa maneira, garante possibilidades de ser disseminado e reproduzido no contexto das organizações pesquisadas, compondo a estruturação social de um campo que, neste caso, é o da educação superior privada no Brasil. 


\section{CONSIDERAÇÕES FINAIS}

O presente estudo ancorou-se na busca de analisar como ocorre a relação entre a racionalidade instrumental e substantiva na prática discursiva organizacional de uma instituição de ensino superior privada.

As racionalidades coexistem na vida organizacional, de modo que, similarmente à Serva (1997, p. 23), “a nossa posição conceitual tem por fundamento a ideia de que a dinâmica do cotidiano das organizações produtivas implica a presença tanto da razão substantiva quanto da razão instrumental". Como tais racionalidades estão em caminhos opostos, suas coexistências e relações podem acarretar conflitos e, nesse estudo, buscamos demonstrar isso, mas também, entender como o poder pode e é usado para conter, silenciar, gerenciar ou controlar tais os conflitos de ação racional.

Em primeiro entendimento, compreendemos as estruturas do Grupo Alpha e da IES Beta, aproximando-as de configurações tipológicas ideais (Mintzberg, 1995), encontrando elementos teóricos e empíricos para se afirmar que a mantenedora tem participação ativa na mantida, por conta de sua estruturação. A pesquisa evidenciou que tal relação ocorre com uma aparente tendência substantiva, onde a lógica advém de que os valores e objetivos nascem e são compartilhados dentro da organização de forma substantiva. Porém, aos aprofundarmos a análise, encontramos traços de que tal inclinação é falsa, onde os que não estão na elite gerencial apenas reproduzem o que acreditam serem os valores, e estes sempre acessam documentos oficiais de modo a se enquadrarem. Neste caso, temos um discurso instrumental que é mascarado para que se incline para o lado racional substantivo.

Desta forma encontramos uma contradição discursiva ante os aspectos valorativos educacionais, onde a mantenedora com sua visão mercantilista, onde o aluno é visto como um cliente, e o papel do professor é ser um mero instrumento repassador de valores de ascensão econômica, e não de valores de visão social e 
política, permanecendo sua meta produzir com qualidade a mercadoria de que é o vendedor. Com isso, temos o silenciamento do valor de ensino-aprendizagem para o consumo-satisfação.

Na questão de tomada de decisão e controle, a organização em estudo se mostrou levemente instrumental; isso demonstra que em algumas práticas a faceta instrumental é mascarada. Assim, quando temos um conflito de racionalidade, o instrumental ganha seu destaque com a anuência dos sujeitos, pois a elite organizacional soube como fazer uso do poder em alguns momentos, quando desejaram se resguardar, ou então, resguardar alguns de seus valores. Os atores abordados nas entrevistas refletiram consciência desse processo, o que se coaduna com os argumentos de Bourdieu (1996; 2001) de que o poder simbólico permite obter o equivalente daquilo que é obtido pela força (física ou econômica), graças ao efeito específico de mobilização de algum tipo de capital, sendo exercido apenas se for reconhecido, quer dizer, ignorado como arbitrário. Ou seja, este poder é uma relação entre quem o exerce e quem a ele está sujeito, criando assim uma crença na legitimidade das palavras e daquele que as pronuncia.

Também apreendemos em nossa análise que, como uma forma de contrabalancear a ação racional mais instrumental apresentada, a IES Beta busca em alguns momentos - sob aspectos pedagógicos - o consenso na resolução de seus conflitos, concedendo uma aparente autonomia para que os atores possam manifestar seu ponto de vista - ainda que sem a certeza de que tal ponto de vista será aceito.

Por fim, esse é o grande discurso que é (re)produzido e que ganha legitimidade dentre os que a ele estão sujeitos e o reproduzindo conscientemente, pela questão que entendemos ser de um poder simbólico utilizado para fazer prevalecer os interesses instrumentais da organização.

Esse estudo nos oferece base para concluir que a relação entre racionalidades numa IES dá-se mediante o uso de um poder simbólico para 'gerenciar' a 
coexistência das racionalidades instrumental e substantiva, onde o grande discurso na organização promulga uma inclinação para a racionalidade substantiva, sendo essa, entretanto, uma sensação falsa, cuja verdadeira intenção é a de mascarar a racionalidade instrumental que sustenta a maior parte dos processos organizacionais selecionados para estudo.

Assim posto, alçamos neste estudo a elaboração de um prisma para analisar o objeto, combinando arranjos metodológicos e análise de dados inéditos até então no estudo teórico-empírico de racionalidade, e que pode ser adaptado a diversos estudos futuros. A escolha do objeto de pesquisa abre espaço para a discussão mais ampla sobre a educação superior no Brasil, pautando-se a partir dos estudos de racionalidades em processos organizacionais, podendo ser extrapolado para estudos na área da educação - em especial, quando se trata de IES, para estudos de práticas andragógicas, bem como para outras discussões acerca do verdadeiro papel da educação superior no Brasil. Recomenda-se, por fim, a combinação de campos e a abertura de caminhos que conduzam ao estudo de outras categorias de IES, como faculdades, institutos superiores de educação, universidades, assim como debruçarse sobre outros processos e discursos organizacionais.

\section{REFERÊNCIAS}

ANDRADE, Sílvia Patricia Cavalheiro de; TOLFO, Suzana da Rosa; DELLAGNELO, Eloise Helena Livramento. Sentidos do Trabalho e Racionalidades Instrumental e Substantiva: Interfaces entre a Administração e a Psicologia. RAC - Revista de Administração Contemporânea, v. 16, n. 2, p. 200-216, Rio de Janeiro, mar./abr. 2012.

BARDIN, L. Análise de conteúdo. 4. ed. Lisboa: Edições 70, 2010.

BARREYRO, Gladys Beatriz; ROTHEN, José Carlos. "SINAES" contraditórios: considerações sobre a elaboração e implantação do sistema nacional de avaliação da 
educação superior. Educação \& Sociedade, Especial, v. 27, n. 96, p. 955-977, Campinas, out. 2006.

BATISTA, Sueli Soares dos Santos. Teoria Crítica e teorias educacionais: Uma análise do discurso sobre educação. Educação \& Sociedade, v. 21, n. 73, p. 182-205, Campinas, 2000.

BRAGA, Kátia S. Aspectos relevantes para a seleção de metodologia adequada à pesquisa social em Ciência da Informação. In: MUELLER, Suzana P. M. (Org.). Métodos para pesquisa em Ciência da Informação. Brasília: Thesaurus, 2007.

BOURDIEU, P. A economia das trocas linguísticas: o que falar quer dizer. São Paulo: Editora da Universidade de São Paulo, 1996.

. 0 poder simbólico. 4. ed. Rio de Janeiro: Bertrand Brasil, 2001.

A economia das trocas simbólicas. São Paulo: Perspectiva, 2005.

BRASIL. Lei de Diretrizes e Bases da Educação Nacional. Lei 9.394/96. Brasília: Imprensa Oficial, Diário Oficial da União, v. 134, n. 248, 1996.

Institui o sistema nacional de avaliação da educação superior - SINAES e dá outras providências. Lei 10.861/04. Brasília: Imprensa Oficial, Diário Oficial da União, v. 45, n. 72, 2004.

CHAUI, Marilena. Convite à filosofia. São Paulo: Ática, 2000.

A universidade pública sob nova perspectiva. Revista Brasileira de Educação, v. 24, p. 5-15, Rio de Janeiro, 2003.

COLOSSI, Nelson. Educação superior em administração: uma concepção substantiva. Revista de Ciências da Administração, v. 1, p. 37-42, Santa Catarina, 1998.

; CONSENTINO, Aldo; QUEIROZ, Etty Guerra de, Mudanças no contexto do ensino superior no brasil: Uma tendência ao ensino colaborativo. Revista FAE, v. 4, n. 1, p. 49-58, Curitiba, jan./abr. 2001.

CUNHA, Maria Isabel da; FAGUNDES, Maurício Cezar Vitória. Discutindo Projetos emancipatórios no contexto da universidade pública no Brasil. Cadernos de Educação, n. 30, Pelotas, 2012. 
EISENHARDT, K. M.; GRAEBNER, M. E. Theory building from cases: opportunities and challenges. Academy of Management Journal, v. 50, n. 1, p. 25-32, New York, 2007.

FAIRCLOGH, Norman. Discurso e mudança social. Brasília: Editora Universidade de Brasília, 2001.

FARINELLI, Clairna Andresa; MELO, Marlene Catarina de Oliveira Lopes. A gerência intermediária da IES: a coordenação de curso e o coordenador como gestor. COLÓQUIO INTERNACIONAL SOBRE GESTÃO UNIVERSITÁRIA NA AMÉRICA DO SUL, 9. Florianópolis, 2009.

GODOY, A. S. Estudo de Caso qualitativo. In: GODOI, C. K.; BANDEIRA-DE-MELO, R. SILVA, A. B. (Org.). Pesquisa qualitativa em estudos organizacionais: paradigmas, estratégias e modelos. São Paulo: Saraiva, 2006. p. 115-146.

HARTLEY, J. Case study research. In: CASSEL, C.; SYMON, G. (Ed.). Essential guide to qualitative methods in organizational research. London, Thousand Oaks, CA \& New Dehli: Sage Publications, 2004. p. 323-333.

IPARDES. Caderno Estatístico Município de Curitiba. Disponível em: $<$ http://www.ipardes.gov.br/cadernos/Montapdf.php?Municipio=80000>. Acesso em: 26 nov. 2018.

INEP. MEC e Inep divulgam dados do Censo da Educação Superior 2016. Disponível em: <http://portal.inep.gov.br/artigo//asset_publisher/B4AQV9zFY7Bv/content/mec-e-inep-divulgam-dados-do-censoda-educacao-superior-2016/21206>. Acesso em 26 Mar. 2018.

LEITCH, Shirley; PALMER, Ian. Analysing texts in context: current practices and new protocols for critical discourse analysis in organization studies. Journal of Management Studies, v. 47, n. 6, p. 1194-1212, Malden, September, 2010.

LOPES, Eduardo Simonini. O sonhar emancipatório e a educação. Educação (UFSM), v. 1, n. 1, p. 125-138, Santa Catarina, 2010.

MINTZBERG, Henry. Criando organizações eficazes: estruturas em cinco configurações. São Paulo: Atlas, 1995.

MÜHL, Eldon Henrique. Violência, racionalidade instrumental e a perspectiva educacional comunicativa. Cadernos de Educação FAE/PPGE/UFPel, n. 33, p. 251274, Pelotas, maio/ago. 2009. 
NASCIMENTO, Eunice Maria; SAYED, Kassen Mohamed El. Administração de Conflitos. In: Gestão do capital humano, volume V, Coleção Gestão Empresarial FAE Business School. Curitiba: Editora Gazeta do Povo, 2002, cap. 4, p. 47-56. Disponível em: <http://www.fae.edu/publicacoes/colecao_gestao.asp>. Acesso em: 26 nov. 2018.

PAULA, Ana Paula Paes de. Guerreiro Ramos: resgatando o pensamento de um sociólogo crítico das organizações. Organização \& Sociedade, v. 14, n. 40, Belo Horizonte, jan./mar. 2007.

RAMOS, Alberto Guerreiro. A nova ciência das organizações: uma reconceituação da riqueza das nações. 2. ed. Rio de Janeiro: FGV, 1989.

ROSA, Alexandre Reis; PAÇO-CUNHA, Elcemir; MORAIS, César Augusto Tureta de. Análise crítica do discurso como análise crítica das organizações: uma proposta teórico-metodológica com base na teoria simbólica de Pierre Bourdieu. In: CARRIERI, Alexandre de Pádua (Org.). Análise do discurso em estudos organizacionais. Curitiba: Juruá, 2009. p. 79-108.

SERVA, Maurício. Racionalidade e Organizações: o fenômeno das organizações substantivas. 633f. Tese (Doutorado em Administração) EAESP/FGV, 1996.

A Racionalidade Substantiva demonstrada na prática administrativa. ERA Revista de Administração de Empresas, v. 37, n. 2, p. 18-30, São Paulo, abr./jun. 1997.

; CAITANO, D.; SANTOS, L.; SIQUEIRA, G. A análise da racionalidade nas organizações - um balanço do desenvolvimento de um campo de estudos no Brasil. Cadernos EBAPE.BR, v. 13, p. 414-437, 2015.

SENO, J. P.; KAPPEL, L. B.; VALADÃO JÚNIOR, V. M. As percepções do professor universitário da área de gestão acerca das mudanças na educação superior: uma pesquisa com profissionais de Instituições de Ensino Privadas do Triângulo Mineiro. Gestão \& Regionalidade, v. 30, n. 88, p. 49-61, São Caetano do Sul, 2014.

SPINK, Mary Jane P.; LIMA, Helena. Rigor e visibilidade: a explicitação dos passos da interpretação. In: SPINK, Mary Jane P. (Org.). Práticas discursivas e produção de sentidos no cotidiano: aproximações teóricas e metodológicas. 2. ed. São Paulo: Cortez, 2000. p. 93-122. 
STAKE, R. E. Case studies. In: DENZIN, N. K.; LINCOLN, Y. S. (Ed.). The SAGE handbook of qualitative research. 2. ed. Thousand Oaks, CA \& New Dehli: Sage Publications, 2000. p. 435-454.

STOHL, Cynthia; CHENEY, George. Participatory Processes/Paradoxical Practices: Communication and the Dilemmas of Organizational Democracy. Management Communication Quarterly, v. 14, n. 3, p. 349-407, February 2001.

VEIGA, Ilma Passos Alencastro. Inovações e projeto político-pedagógico: uma relação regulatória ou emancipatória. Caderno CEDES, v. 23, n. 61, p. 267-281, Campinas, 2003.

YIN, R. K. Estudo de caso: planejamento e métodos. 3. ed. Porto Alegre: Bookman, 2005. 